\title{
Switching deformation mode and mechanisms during subduction of continental crust: a case study from Alpine Corsica
}

\author{
Giancarlo Molli ${ }^{1}$, Luca Menegon ${ }^{2}$, and Alessandro Malasoma ${ }^{3}$ \\ ${ }^{1}$ Dipartimento di Scienze della Terra, Università di Pisa, Via S. Maria, 53, Pisa 56126, Italy \\ ${ }^{2}$ School of Geography, Earth and Environmental Sciences, Plymouth University, Plymouth, UK \\ ${ }^{3}$ TS Lab and Geoservices, Via Vecchia Fiorentina, 10, Cascina 56023, Pisa, Italy \\ Correspondence to: Giancarlo Molli (giancarlo.molli@unipi.it)
}

Received: 31 January 2017 - Discussion started: 7 February 2017

Revised: 12 May 2017 - Accepted: 7 June 2017 - Published: 13 July 2017

\begin{abstract}
The switching in deformation mode (from distributed to localized) and mechanisms (viscous versus frictional) represent a relevant issue in the frame of crustal deformation, being also connected with the concept of the brittle"ductile" transition and seismogenesis. In a subduction environment, switching in deformation mode and mechanisms and scale of localization may be inferred along the subduction interface, in a transition zone between the highly coupled (seismogenic zone) and decoupled deeper aseismic domain (stable slip). However, the role of brittle precursors in nucleating crystal-plastic shear zones has received more and more consideration being now recognized as fundamental in some cases for the localization of deformation and shear zone development, thus representing a case in which switching deformation mechanisms and scale and style of localization (deformation mode) interact and relate to each other. This contribution analyses an example of a millimetrescale shear zone localized by brittle precursor formed within a host granitic protomylonite. The studied structures, developed in ambient pressure-temperature $(P-T)$ conditions of low-grade blueschist facies (temperature $T$ of ca. $300^{\circ} \mathrm{C}$ and pressure $P \geq 0.70 \mathrm{GPa}$ ) during involvement of Corsican continental crust in the Alpine subduction. We used a multidisciplinary approach by combining detailed microstructural and petrographic analyses, crystallographic preferred orientation by electron backscatter diffraction (EBSD), and palaeopiezometric studies on a selected sample to support an evolutionary model and deformation path for subducted continental crust. We infer that the studied structures, possibly formed by transient instability associated with fluctuations of pore fluid pressure and episodic strain rate variations, may be consid-
\end{abstract}

ered as a small-scale example of fault behaviour associated with a cycle of interseismic creep and coseismic rupture or a new analogue for episodic tremors and slow-slip structures. Our case study represents, therefore, a fossil example of association of fault structures related to stick-slip strain accommodation during subduction of continental crust.

\section{Introduction}

The study of deformation fabric of fault rocks has been crucial for the development of a general conceptual model for crustal-scale fault zones (Sibson, 1977, 1983; Scholz, 1988, 2002; Handy et al., 2007; Cooper et al. 2010; Platt and Behr, 2011). In this model, the increasing PT conditions determine the transition from a seismogenic frictional regime, dominated by pressure-sensitive deformation and involving cataclasis and frictional sliding, to a viscous regime (Rutter, 1986; Schmid and Handy, 1991; Montési and Hirth, 2003; Handy and Brun, 2004), where dominantly aseismic, mainly crystal-plastic and continuous shearing is localized within mylonitic shear zones. In quartz-feldspathic rocks, this transition is primarily determined by the temperature-related quartz response to change of deviatoric stress, with dislocation creep becoming the principal deformation mechanism at $T>270^{\circ} \mathrm{C}$ (e.g. White, 1971, 1973; Stipp et al., 2002, and references therein).

Rock deformation experiments (Rutter, 1986; Shimamoto and Logan, 1986; Bos and Spiers 2002; Scholz, 2002) have shown that the shear strength of simulated faults at the brittle-viscous transition may depend on normal stress (as 
with faulting dominated by cataclastic mechanisms) although strain is achieved through crystal plasticity and/or solution transfer. These results support the observations that some mylonitic shear zones are produced by coupled frictional and viscous mechanisms under semi-brittle conditions (Shimamoto and Logan, 1986; Shimamoto, 1989; Chester, 1989; Scholz, 2002; Pec et al., 2012, and references therein). The experimental approach on semi-brittle behaviour, however, still leaves several questions open for natural fault zones, such as the mechanisms controlling bulk-rock deformation at microscopic scale, the degree of interdependence of active deformation mechanisms, their cyclicity, and the associated bulk rock style of deformation (Sibson, 1980; White and White, 1983; Viola et al., 2006; Takagi et al., 2000; Handy and Brun, 2004; Pec et al., 2012). A complex transitional behaviour involving mixed continuous and discontinuous, distributed vs. localized, and cyclic switching in deformation mechanisms over large variations in strain rates is inferred at the transition between frictional and viscous domains, a depth interval in the crust which contains the typical hypocentres and rupture depths of large earthquakes in continental crust (Sibson, 1983; Kohlstedt et al., 1995; Scholz, 2002; Handy and Brun, 2004; Pennacchioni et al., 2006).

In subduction settings, this transition zone is located between 10 and $35 \mathrm{~km}$ depth depending on slab dip and thermal structure (i.e. between temperatures of 150 and $350-450^{\circ} \mathrm{C}$ ) and along the subduction interface is recognized as the site of megathrust earthquake nucleation and concentrated postseismic afterslip, as well as the focus site of episodic tremors and slow-slip events (Rogers and Dragert, 2003; Liu and Rice, 2007; Hacker et al., 2003; Vannucchi et al., 2008; Meneghini et al., 2010; Angiboust et al., 2014, 2015; Andersen et al., 2014; Hayman and Lavier, 2014; Fagereng et al., 2014).

The feedback between brittle and viscous deformation mechanisms is also relevant for the mode of shear zone nucleation, and fracturing has been proposed to be a prerequisite for the initiation of ductile shear zones in the lithosphere (e.g. Handy and Stünitz, 2002; Pennacchioni and Mancktelow, 2007; Fusseis and Handy, 2008). Shear zones and style of strain accommodation and localization processes in granitoids have been described by different authors (Ramsay and Graham, 1970; Burg and Laurent, 1985, 1986; Gapais et al., 1987; Goncalves et al., 2016, and references therein). In this context, the role of brittle precursors in nucleating shear zones has received increasing consideration as having in some cases a fundamental role in the localization process (e.g. Segall and Simpson, 1986; Mancktelow and Pennacchioni, 2005; Pennacchioni, 2005; Pennacchioni and Mancktelow, 2007; Menegon and Pennacchioni, 2010; Pennacchioni and Zucchi, 2013).

These studies, however, mostly deal with brittle precursors consisting of inherited structures, such as discontinuities already existing at the beginning of the viscous deformation history, as in the case of cooling joints, cataclasites, and veins (e.g. Guermani and Pennacchioni, 1998; Pennacchioni and Mancktelow 2007); most of these studies consider deformation at shallow to intermediate crustal depths (Fusseis and Handy, 2008; Mazzoli et al., 2009; Molli et al., 2011), although case studies under conditions of upper amphibolite to granulite (White, 1996; Pennacchioni and Cesare, 1997; Pittarello et al., 2013; Altenberger et al., 2013) and eclogite facies (Austrheim and Boundy, 1994; Austrheim, 2013, and references therein) were also investigated.

The deformation of crustal units and granitoids during subduction has only recently been analysed in terms of preserved rock records of the palaeo-seismic cycle and/or slow-slip phenomena (Angiboust et al., 2015; Goncalves et al., 2016). A well-documented study from the Dent Blanche Thrust in the western Alps, for example, is framed in the hanging wall of an ancient subduction interface zone (Angiboust et al., 2014, 2015). Our contribution integrates the existing literature by analysing a meso- to microscale example of a brittle precursor to a shear zone derived from the footwall of a subduction interface in blueschist-facies conditions thus representing a hitherto undocumented or less thoroughly studied case (Molli et al., 2005; Molli, 2007).

We used a multidisciplinary approach that combined detailed microstructural, petrographic, and electron backscatter diffraction (EBSD) analysis in order to derive a model of the deformation sequence experienced by our sample during subduction of the continental crust in Corsica. EBSD data have been used to identify the dominant deformation and recrystallization mechanisms in quartz, and to derive quantitative grain size data that were used to evaluate the differential stresses experienced by the rock during dislocation creep deformation by means of the recrystallized grain size piezometry.

By virtue of their deep origin, the analysed structures are ideal to contribute to the ongoing discussion on the deformation style and mechanisms associated with the broad spectrum of fault-slip behaviour (from seismic slip to stable aseismic creep to episodic slow-slip events and nonvolcanic tremors) recorded by seismic and geodetic observations at active plate boundaries (e.g. Peng and Gomberg, 2010; Beroza and Ide, 2011, and references therein). Slowslip events (i.e. fault slip events with slip rates in between coseismic rate and aseismic creep, and generating equivalent seismic moments similar to large earthquakes) in subduction zones have been recorded in a depth interval that experiences temperatures between 250 and $650^{\circ} \mathrm{C}$ and pressures between 0.6 and $1.2 \mathrm{GPa}$ (Beroza and Ide, 2011), typically in areas of high $V_{\mathrm{p}} / V_{\mathrm{s}}$ ratios suggestive of local high fluid pressures. This places slow-slip events at the lower end of the seismogenic zone, under metamorphic conditions where the rheology is expected to be viscous or at the frictionalviscous transition. Accordingly, recent studies of shear zones exhumed from similar conditions along the subduction interface have suggested that coupled fracture and viscous flow, possibly associated with fluctuations in fluid pressure, can 
originate tremors and slow slips (e.g. Peng and Gomberg, 2010; Beroza and Ide, 2011; White, 2012; Fagereng et al., 2014; Hayman and Lavier, 2014; Angiboust et al., 2015; Malatesta et al., 2017). Here we show that the brittle-viscous transition preserved in the Popolasca granitoids of northern Corsica can also be explained by transient high fluid pressures triggering brittle deformation in an otherwise viscous regime, and discuss the related implications for fault-slip behaviours in subduction zones.

\section{Regional background and geological setting of studied sample}

In Alpine-type orogens the study of meso- and microstructural record of exhumed subduction-related thrust zones and its interpretation in terms of subduction zone rheology and seismicity have received increasing attention since the end of the 1990s (Stöckhert et al.,1999; Küster and Stöckhert, 1999). This subject has been well developed and explored (Austrheim and Andersen, 2004; Andersen and Austrheim, 2006; Healy et al., 2009; Andersen et al., 2014; Deseta et al., 2014a, b; Magott et al., 2016a, b) in northeast Corsica (so-called "Alpine Corsica"), which is formed by relicts of subduction orogen related to the CretaceousMiddle Tertiary Europe-Adria convergence history (Lahondère, 1988; Fournier et al., 1991; Handy et al., 2010; Molli and Malavieille, 2011).

These studies focused on oceanic units made up of peridotite, serpentinite, gabbro, basalt, calcareous and siliceous schist, and marble exposed as remnants of the lithosphere of the Jurassic Piemonte-Liguria oceanic basin and its pelagic sedimentary cover (Mattauer et al., 1981; Bezert and Caby, 1988; Jolivet et al., 1990; Molli, 2008; Vitale Brovarone et al., 2013, and references therein).

The widespread occurrence and preservation of relicts of exhumed seismogenic structures are mainly due to the peculiar geologic history of Alpine Corsica, which is connected with the development of the Alps-Apennine orogenic system (Molli and Malavieille, 2011; Guyedan et al., 2017; Beaudoin et al., 2017). The latter did not develop continentcontinent "hard collision"-related structures and lacks the thermal reworking observable instead in the Alps (e.g. Polino et al., 1995; Schmid et al., 1996; Berger and Busquet, 2008; Butler, 2013; Rosenberg and Kissling, 2013; Carminati and Doglioni, 2014), thus resulting in the better preservation of the early stages of subduction-related structures and fabrics.

Corsica, therefore, represents an exceptional natural laboratory for the investigation of subduction-related processes in oceanic and continental crust, as firstly suggested by Mattauer et al. (1981) and Gibson and Horak (1984).

Continental-derived units in Corsica sourced from the footwall of an ancient subduction interface zone can be observed in three different structural positions (Fig. 1), each of them corresponding to different peak metamorphic con-

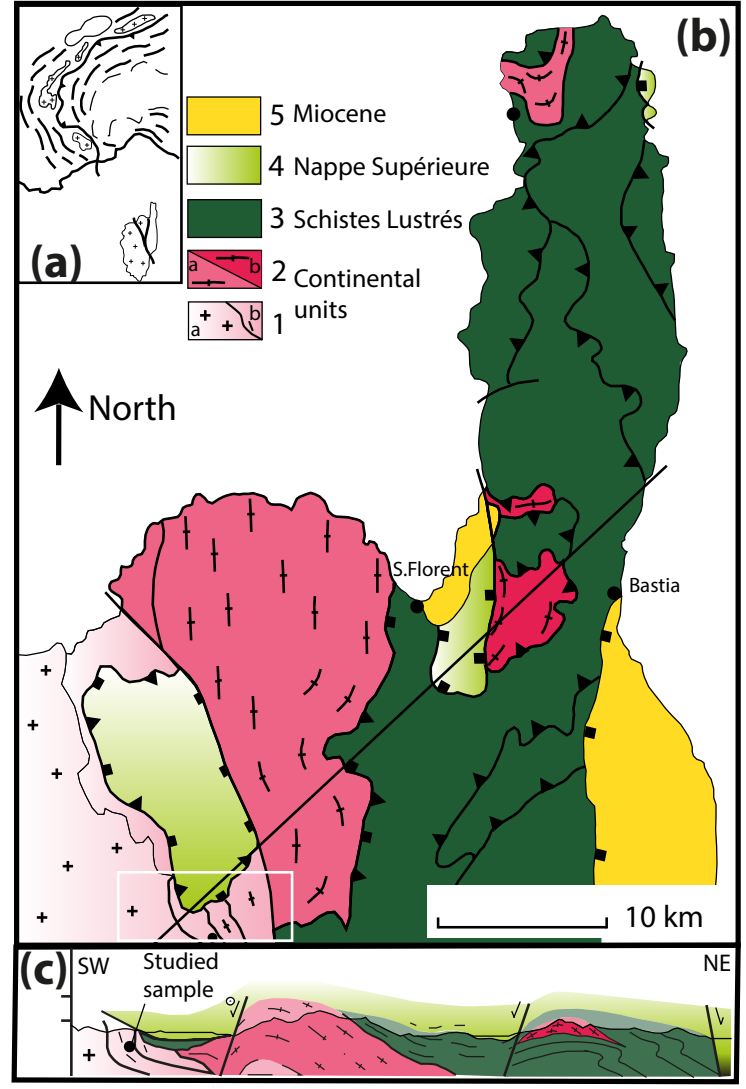

Figure 1. (a) Alpine Corsica within the Alps-Apennine framework. (b) Tectonic map of north Corsica showing the main tectonic units and the area of studied sample. $(1,2)$ Corsican continental crust, mainly Carboniferous-Permian granitoids, their host pre-Carboniferous basement, and a Mesozoic to Eocene cover: (1, a) "autochthonous" Hercynian Corsica and $(1, \mathbf{b})$ greenschist/lowerblueschist external continental units (Corte and Popolasca units); (2) inner continental units: (2, a) upper-blueschist units (Tenda Massif; Centuri) and $(2, \mathbf{b})$ eclogite slices (Serra di Pigno-Farinole); (3) Schistes Lustrés nappe (undifferentiated); (4) Nappe Supérieure i.e. upper non-metamorphic units (Balagne, Nebbio, and Macinaggio units); and (5) Miocene sediments. (c) Regional sketch cross section with location of the studied sample from the Popolasca area.

ditions (Tribuzio and Giacomini, 2004; Molli, 2008; Vitale Brovarone et al., 2013):

1. The innermost slices (Serra di Pigno/Farinole units) interleaved with oceanic units show eclogite peak conditions at $1.5-1.8 \mathrm{GPa} ; 500 \pm 50^{\circ} \mathrm{C}$.

2. The intermediate units (e.g. the Tenda and Centuri units) are instead characterized by upper blueschist facies peak conditions at $0.9-1.1 \mathrm{GPa}, 450 \pm 50^{\circ} \mathrm{C}$.

3. The most external units (e.g. Corte/Popolasca) contain high-pressure greenschist and/or blueschist facies peak assemblages developed at $T=325-370^{\circ} \mathrm{C}, P=0.75$ $0.85 \mathrm{GPa}$ (Malasoma et al., 2006; Di Rosa et al., 2016). 
These occurrences document the progressive underthrusting of these units down to different depths and their insequence contractional exhumation within an Alpine-age, east-dipping subduction system (Mattauer et al., 1981; Bezert and Caby, 1988; Jolivet et al., 1990; Garfagnoli et al., 2009; Molli and Malavieille, 2011; Maggi et al., 2012; Di Rosa et al., 2016; Guyedan et al., 2017; Beaudoin et al., 2017).

The studied samples come from the external continental units (Molli, 2008; Molli and Malavieille, 2011; Vitale Brovarone et al., 2013) of Alpine Corsica, more specifically from the Popolasca unit (Bezert and Caby, 1988; Malasoma et al., 2006; Di Rosa et al., 2016). This unit is characterized by a pre-Mesozoic basement mainly formed by granitoids, a Permo-Mesozoic metasedimentary sequence and an early Eocene flysch (Fig. 1).

Blueschist assemblages in the unit have been described by regional studies (Bezert and Caby, 1988; Malasoma et al., 2006; Molli, 2008; Di Rosa et al., 2016) and are observed in all suitable rock types, such as in metapelites from cover rocks, metabasic dykes, and in some of the granitoid suites from the basement. Peak metamorphism has been initially constrained to $250-350^{\circ} \mathrm{C}$ and $0.4-0.55 \mathrm{GPa}$ (Bezert and Caby, 1988) or more recently more closely bracketed at 325-370 ${ }^{\circ} \mathrm{C}$ and $0.75-0.85 \mathrm{GPa}$ (Malasoma et al., 2006; Di Rosa et al., 2016). The prograde to peak pressure assemblage has been recently dated with ${ }^{40} \mathrm{Ar} /{ }^{39} \mathrm{Ar}$ at $45-36 \mathrm{Ma}$ by $\mathrm{Di}$ Vincenzo et al. (2016).

The contributions of Malasoma et al. (2006) and Di Rosa et al. (2016) analysed the cartographic to mesoscopic-scale structural geometries of deformation in the area of the studied sample. Superimposed foliations and fold structures are typical of the metasedimentary cover, with blueschist assemblages as relict fabrics. In contrast, in basement rocks a main continuous foliation can be observed wrapping around undeformed granitoids. The main foliation is associated with blueschist or greenschist facies assemblages (Malasoma et al., 2005; Di Rosa et al., 2016; Di Vincenzo et al., 2016). Anastomosing networks of fault zones associated with sub-greenschist facies assemblages overprints all previous structures and may be related to the activity of a major N-S-trending transcurrent fault zone (Central Corsica Fault Zone) reworked by normal kinematics active during Oligocene-Miocene in the frame of rototranslation of Corsica-Sardinia microblock and upper-plate extension associated with Apenninic subduction (Faccenna et al., 2004; Molli, 2008; Molli and Malavieille, 2011; Carminati and Doglioni, 2014; Guyedan et al., 2017; Beaudoin et al., 2017).

\section{Geometry of deformation and microstructures}

The analysed sample (Fig. 2) is a deformed granitoid of calc-alkaline affinity (K-feldspar, plagioclase, quartz, biotite) common to Hercynian Corsica (Rossi et al., 2001). It con-
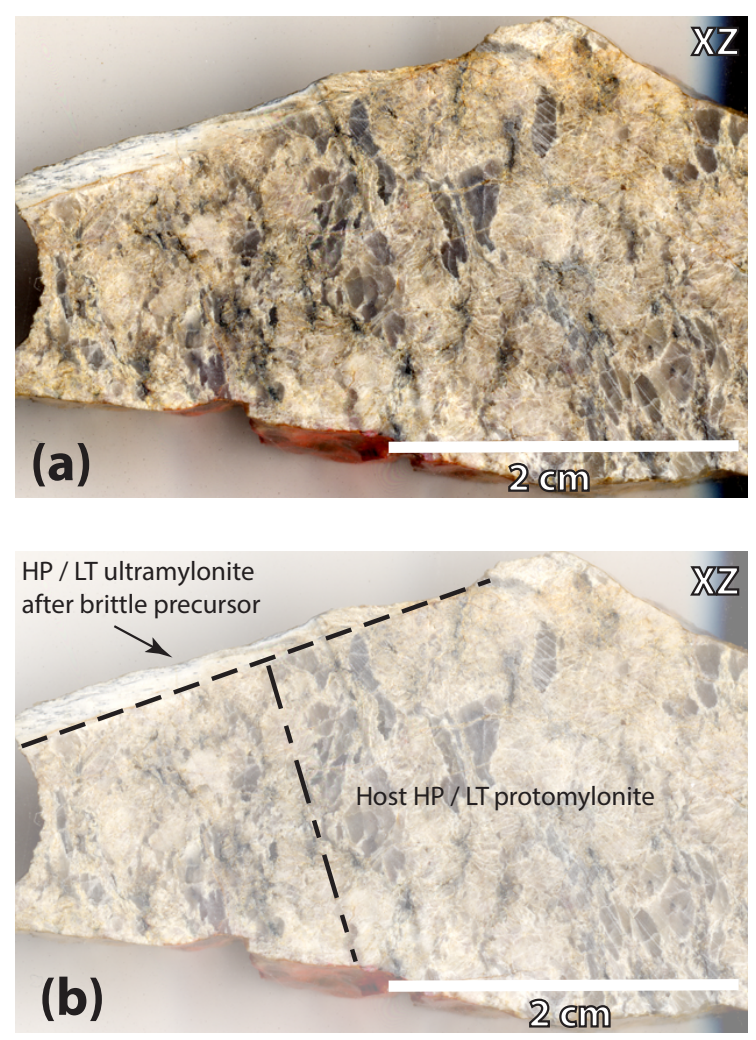

Figure 2. The analysed sample of a protomylonitic metagranite with millimetre-scale ultramylonite (compare $\mathbf{a}$ and $\mathbf{b}$ ). The dashed lines in (b) are the trace of foliation in the protomylonitic host and the sharp shear zone boundary of the ultramylonite developed after a brittle precursor. All observable deformation structures were developed under high-pressure, low-temperature (HP/LT) metamorphic conditions.

tains a continuous foliation (Figs. 2, 3a, b) mainly defined by the shape preferred orientation of quartz, feldspars, and biotite grains.

Shape anisotropy of quartz in the host protomylonite shows an aspect ratio around 0.37 (mean $X / Z$ of 2.7), which indicates a shear strain $\gamma$ of ca. 1 assuming homogeneous simple shear deformation.

Quartz displays features of typical low-temperature plasticity (Hirth and Tullis, 1992; Stipp et al., 2002; Vernooij et al., 2006; Trepmann et al., 2007; Derez et al., 2015; Kjøll et al., 2015) (Fig. 3), such as undulatory extinction, localized extinction bands (LEBs, following the terminology of Derez et al., 2015), typically forming conjugate sets, and up to $100 \mu \mathrm{m}$ thick intracrystalline bands of recrystallized grains $(5-10 \mu \mathrm{m}$ in size). Bands of recrystallized grains occur parallel to the main foliation as well as in conjugate sets intersecting at ca. $90^{\circ}$ (see below) and parallel to the conjugate sets of LEBs.

Feldspars show local evidence of bulging recrystallization and of grain size reduction by microcracking and microfaulting (Fig. 3), often associated with K-feldspar breakdown to 

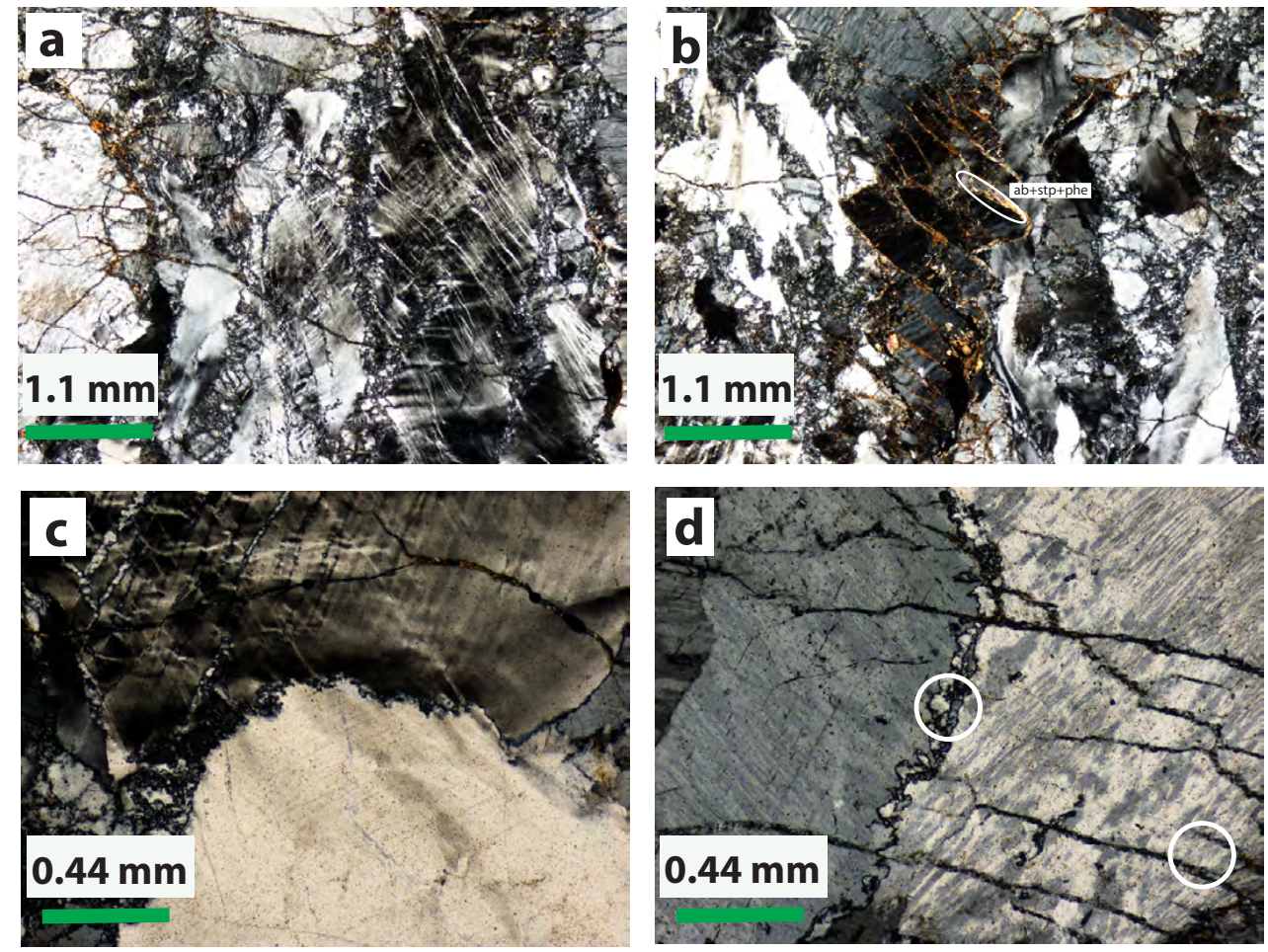

Figure 3. Microphotographs of host-protomylonite showing quartz microstructures typical of low-temperature plasticity: (a) intracrystalline deformation (undulatory extinction, deformation lamellae, deformation bands, localized extinction bands, LEBs) associated with recrystallization along intragranular conjugate shear bands sets; (b) domino-style brittle fracturing of K-feldspar and associated K-feldspar breakdown to albite, stilpnomelane, and phengite; (c) quartz deformation lamellae and intergranular recrystallization by bulging; and (d) K-feldspar intergranular recrystallization and albite neocrystallization and recrystallization also observable along later cracks and microfractures (horizontal to sub-horizontal).

albite, stilpnomelane, and phengite (Fig. 3). Thin needles of $\mathrm{Na}$ amphibole (Fig. 4) attest the development of this fabric in high-pressure, low-temperature (HP/LT) conditions as described below.

The main foliation is cross-cut at a high angle by a millimetre-thick localized zone of deformation (Figs. 2, 5a). This shows a sharp boundary, truncating flattened quartz and feldspar grains (Figs. 6, 7) - a feature suggesting its development as an unstable fracture (Schmid and Handy, 1991; Passchier and Trouw, 2011).

Three compositionally controlled domains can be recognized within the thin localized shear zone (Figs. 2, 5):

Domain 1 is feldspar- and quartz-dominated and shows microstructural features typical of a cataclastic rock (Fig. 5a, c). Clasts are embedded in a fine-grained matrix $(<10-20 \mu \mathrm{m}$ in size) present in a patchy variable amounts in different portions of the cataclasite (from less than $10 \%$ to more than $50 \%$, Fig. 5b, c, f). The clasts show angular shapes and a polymodal grain size distribution (Fig. 5d-g).

Feldspar clasts and quartz grains reveal both displacive intragranular fractures and intergranular "stable" cracks (Atkinson, 1982; Schmid and Handy, 1991). The clasts show relict microstructural features similar to those found in the host protomylonite, such as intracrystalline recrystallized shear bands, which in some cases (where the clasts were not substantially rotated, Fig. 5c-f) have the same geometry and orientation as those observed in the host protomylonite (Fig. 5d-g).

Domain 2 is "phyllosilicate"-dominated (stilpnomelane and phengite) and shows microstructural features of a foliated-cataclasite/phyllonite (Figs. 5a, 6). Asymmetric porphyroclasts and shear band systems characterize the phyllosilicate-rich parts of the shear zone (Fig. 6a-d).

Domain 3 is a quartz-albite-rich domain showing microstructural features typical of an ultramylonite (Figs. 5a, 7). This is characterized by very fine recrystallized albite and quartz grains $(5-10 \mu \mathrm{m}$ in size) (Fig. 7) with strong crystallographic preferred orientation (see below). Quartz porphyroclasts show a mean aspect ratio around 0.09 (mean $X / Z$ of 11), which corresponds to a calculated shear strain $\gamma$ of ca. 3. At this shear strain the corresponding angle between the foliation and the shear zone boundary in simple shear is around $15^{\circ}$, which agrees with the mean orientation of the quartz porphyroclasts shape preferred orientation (SPO) defining the ultramylonitic foliation (Fig. 7a-c). Syn- to post- 
Table 1. Representative microprobe analyses (wt \%) of coesisting minerals within the metamorphic assemblage. Na-amphiboles structural formulae were calculated assuming 23 oxygens per anhydrous formula unit.

\begin{tabular}{|c|c|c|c|c|c|c|c|c|c|}
\hline Amphibole & Am1 & Am3 & Am4 & Am5 & Am6N & Am6B & Am7 & Am8 & Am9 \\
\hline \multicolumn{10}{|l|}{$\mathrm{Wt} \%$} \\
\hline $\mathrm{SiO}_{2}$ & 51.58 & 51.30 & 50.62 & 50.97 & 50.28 & 50.61 & 52.62 & 51.26 & 51.10 \\
\hline $\mathrm{TiO}_{2}$ & 0.35 & 0.32 & 0.52 & 0.24 & 0.20 & 0.39 & 0.16 & 0.20 & 0.14 \\
\hline $\mathrm{Al}_{2} \mathrm{O}_{3}$ & 1.67 & 1.89 & 1.97 & 1.73 & 2.22 & 1.85 & 2.59 & 1.74 & 1.87 \\
\hline $\mathrm{Cr}_{2} \mathrm{O}_{3}$ & 0.00 & 0.00 & 0.00 & 0.00 & 0.00 & 0.00 & 0.00 & 0.00 & 0.00 \\
\hline $\mathrm{FeO}$ & 28.13 & 29.65 & 28.80 & 28.77 & 30.25 & 30.18 & 27.94 & 30.06 & 29.57 \\
\hline $\mathrm{MnO}$ & 0.00 & 0.15 & 0.00 & 0.20 & 0.00 & 0.00 & 0.00 & 0.10 & 0.00 \\
\hline $\mathrm{MgO}$ & 2.24 & 1.86 & 1.97 & 2.16 & 1.64 & 1.98 & 1.90 & 1.89 & 2.24 \\
\hline $\mathrm{CaO}$ & 0.06 & 0.05 & 0.10 & 0.09 & 0.13 & 0.14 & 0.06 & 0.08 & 0.05 \\
\hline $\mathrm{Na}_{2} \mathrm{O}$ & 6.44 & 6.63 & 6.66 & 6.79 & 6.02 & 6.42 & 6.88 & 6.73 & 6.97 \\
\hline $\mathrm{K}_{2} \mathrm{O}$ & 0.41 & 0.39 & 0.46 & 0.38 & 0.35 & 0.43 & 0.71 & 0.29 & 0.29 \\
\hline TOT & 90.88 & 92.24 & 91.10 & 91.33 & 91.09 & 92.00 & 92.86 & 92.35 & 92.23 \\
\hline \multicolumn{10}{|l|}{ Cations } \\
\hline $\mathrm{Si}$ & 8.16 & 8.09 & 8.09 & 8.11 & 8.07 & 8.05 & 8.17 & 8.09 & 8.08 \\
\hline Al IV & 0.00 & 0.00 & 0.00 & 0.00 & 0.00 & 0.00 & 0.00 & 0.00 & 0.00 \\
\hline Sum $T$ & 8.16 & 8.09 & 8.09 & 8.11 & 8.07 & 8.05 & 8.17 & 8.09 & 8.08 \\
\hline $\mathrm{Al} \mathrm{VI}$ & 0.31 & 0.35 & 0.37 & 0.32 & 0.42 & 0.35 & 0.47 & 0.32 & 0.35 \\
\hline $\mathrm{Fe}_{3}+$ & 1.70 & 1.56 & 1.42 & 1.54 & 1.46 & 1.50 & 1.45 & 1.59 & 1.50 \\
\hline $\mathrm{Ti}$ & 0.04 & 0.04 & 0.06 & 0.03 & 0.02 & 0.05 & 0.02 & 0.02 & 0.02 \\
\hline $\mathrm{Cr}$ & 0.00 & 0.00 & 0.00 & 0.00 & 0.00 & 0.00 & 0.00 & 0.00 & 0.00 \\
\hline $\mathrm{Mg}$ & 0.53 & 0.44 & 0.47 & 0.51 & 0.39 & 0.47 & 0.44 & 0.44 & 0.53 \\
\hline $\mathrm{Fe}_{2}+$ & 2.02 & 2.35 & 2.43 & 2.28 & 2.61 & 2.51 & 2.18 & 2.38 & 2.41 \\
\hline $\mathrm{Mn}$ & 0.00 & 0.02 & 0.00 & 0.03 & 0.00 & 0.00 & 0.00 & 0.01 & 0.00 \\
\hline Sum C & 4.60 & 4.76 & 4.75 & 4.71 & 4.90 & 4.88 & 4.56 & 4.76 & 4.81 \\
\hline $\mathrm{Mg}$ & 0.00 & 0.00 & 0.00 & 0.00 & 0.00 & 0.00 & 0.00 & 0.00 & 0.00 \\
\hline $\mathrm{Mn}$ & 0.00 & 0.00 & 0.00 & 0.00 & 0.00 & 0.00 & 0.00 & 0.00 & 0.00 \\
\hline $\mathrm{Fe}_{2}^{+}$ & 0.00 & 0.00 & 0.00 & 0.00 & 0.00 & 0.00 & 0.00 & 0.00 & 0.00 \\
\hline $\mathrm{Ca}^{2}$ & 0.01 & 0.01 & 0.02 & 0.02 & 0.02 & 0.02 & 0.01 & 0.01 & 0.01 \\
\hline $\mathrm{Na}$ & 1.97 & 1.99 & 1.98 & 1.98 & 1.87 & 1.98 & 1.99 & 1.99 & 1.99 \\
\hline Sum B & 1.98 & 2.00 & 2.00 & 2.00 & 1.89 & 2.00 & 2.00 & 2.00 & 2.00 \\
\hline $\mathrm{Na}$ & 0.00 & 0.04 & 0.08 & 0.11 & 0.00 & 0.00 & 0.08 & 0.07 & 0.14 \\
\hline K & 0.08 & 0.08 & 0.09 & 0.08 & 0.07 & 0.09 & 0.14 & 0.06 & 0.06 \\
\hline Sum A & 0.08 & 0.12 & 0.17 & 0.19 & 0.07 & 0.09 & 0.22 & 0.13 & 0.20 \\
\hline TOT & 14.82 & 14.97 & 15.01 & 15.01 & 14.93 & 15.02 & 14.95 & 14.98 & 15.09 \\
\hline
\end{tabular}

-: below detection limits

kinematic Na amphibole (Fig. 7c, d) documents shearing in HP/LT metamorphic conditions, as illustrated below.

It is worth noting that no fractures or cataclastic fabrics overprint the ultramylonite. This demonstrates that the ultramylonites postdate and rework a former cataclastic band (and exploits it as a nucleation site), which in turn developed after the protomylonitic fabric in the host rock.

\section{Mineral chemistry and estimate of metamorphic pressure-temperature $(P-T)$ conditions}

Chemical analyses of coexisting minerals within the metamorphic assemblage (Tables 1, 2, 3) were obtained using a JEOL JXA-8600 electron microprobe, equipped with four wavelength-dispersive spectrometers, at the CNR - Istituto di Geoscienze e Georisorse, Firenze, Italy. Running conditions were $15 \mathrm{kV}$ accelerating voltage and $10 \mathrm{nA}$ beam current on a Faraday cage. Counting time for the determined elements 


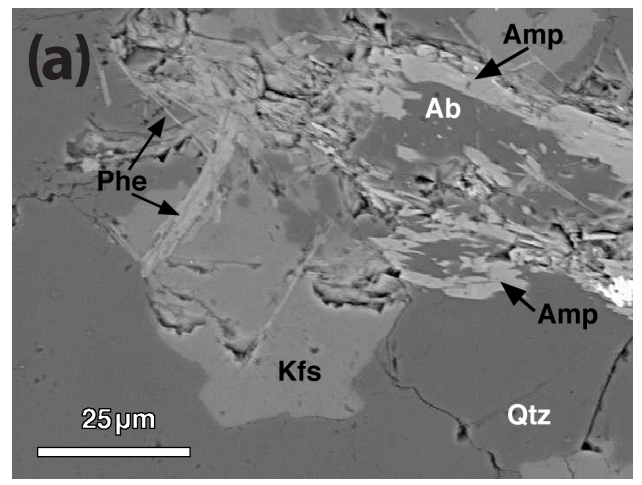

Table 2. Representative microprobe analyses of Stilpnomelane whose structural formulae were calculated assuming 24 oxygens and all $\mathrm{Fe}$ as divalent $\left(\mathrm{Fe}_{2}^{+}\right)$.

\begin{tabular}{|c|c|c|c|c|}
\hline Stilpnomelane & phyll 1 & phyll 2 & phyll 3 & phyll 4 \\
\hline \multicolumn{5}{|l|}{$\mathrm{Wt} \%$} \\
\hline $\mathrm{SiO}_{2}$ & 45.20 & 48.73 & 40.85 & 42.13 \\
\hline $\mathrm{TiO}_{2}$ & 0.13 & 0.07 & 0.30 & 0.18 \\
\hline $\mathrm{Al}_{2} \mathrm{O}_{3}$ & 21.19 & 12.22 & 17.08 & 20.28 \\
\hline $\mathrm{Cr}_{2} \mathrm{O}_{3}$ & - & 0.11 & - & - \\
\hline $\mathrm{FeO}$ & 13.54 & 20.45 & 19.60 & 16.13 \\
\hline $\mathrm{MnO}$ & - & 0.16 & - & - \\
\hline $\mathrm{MgO}$ & 2.39 & 0.95 & 1.94 & 1.92 \\
\hline $\mathrm{CaO}$ & 0.16 & 0.20 & 0.29 & 0.32 \\
\hline $\mathrm{Na}_{2} \mathrm{O}$ & 0.16 & 1.00 & 0.37 & 0.26 \\
\hline $\mathrm{K}_{2} \mathrm{O}$ & 4.68 & 3.00 & 5.05 & 4.89 \\
\hline TOT & 87.45 & 86.89 & 85.48 & 86.11 \\
\hline \multicolumn{5}{|l|}{ Cations } \\
\hline $\mathrm{Si}$ & 7.418 & 8.292 & 7.235 & 7.200 \\
\hline $\mathrm{Al}$ vi & 1.582 & 0.708 & 1.765 & 1.800 \\
\hline Sum Z & 9.000 & 9.000 & 9.000 & 9.000 \\
\hline $\mathrm{Al}$ iv & 2.516 & 1.743 & 1.800 & 2.284 \\
\hline $\mathrm{Ti}$ & 0.016 & 0.009 & 0.040 & 0.023 \\
\hline $\mathrm{Cr}$ & 0.000 & 0.015 & 0.000 & 0.000 \\
\hline $\mathrm{Fe}_{3}^{+}$ & 0.000 & 0.000 & 0.000 & 0.000 \\
\hline $\mathrm{Fe}_{2}^{+}$ & 1.858 & 2.909 & 2.902 & 2.304 \\
\hline $\mathrm{Mn}$ & 0.000 & 0.023 & 0.000 & 0.000 \\
\hline $\mathrm{Mg}$ & 0.584 & 0.241 & 0.512 & 0.489 \\
\hline Sum Y & 4.974 & 4.939 & 5.254 & 5.100 \\
\hline $\mathrm{Ca}$ & 0.028 & 0.036 & 0.055 & 0.059 \\
\hline $\mathrm{Na}$ & 0.051 & 0.330 & 0.127 & 0.086 \\
\hline $\mathrm{K}$ & 0.979 & 0.651 & 1.141 & 1.066 \\
\hline Sum X & 1.058 & 1.017 & 1.323 & 1.210 \\
\hline TOT & 15.032 & 14.956 & 15.576 & 15.311 \\
\hline
\end{tabular}

Figure 4. (a) Backscattered electron image of the metamorphic mineral assemblage in the host granitoids of the studied sample; Ab, albite; Amp, Na amphibole; Kfs, K-feldspar; Phe, phengite; and Qtz, quartz. (b) Composition of sodic amphiboles, using the classification of Leake et al. (1997). (c) Estimated peak-metamorphic pressure and temperature conditions for the studied sample (crosshatched area) constrained by the reactions indicated.

ranged from 10 to $60 \mathrm{~s}$ at both peak and background. The Bence and Albee (1968) method was employed for the correction of all data. A number of synthetic and mineral standards were used for instrumental calibration.

Structural formulae of amphiboles were calculated assuming 23 oxygens, and the classification of Leake et al. (1997) was adopted. Site assignment and ferric iron contents were calculated using the scheme proposed by Schumacher in Leake et al. (1997). Because of the small sizes of the crystals (widths ca. $10 \mu \mathrm{m}$ ), it was not possible to make com-

- : below detection limit

positional traverses across individual crystals to detect intracrystalline variations in chemical composition, such as core-to-rim zonation. Thus, each analysis reported in Table 1 is from a different crystal. In the studied sample the $\mathrm{Na}$ amphiboles are mostly riebeckite (Table 1 and Fig. 4b) with low $\mathrm{Mg} /\left(\mathrm{Mg}+\mathrm{Fe}^{2+}\right)$ ratio (0.13-0.21) and are characterized by $\mathrm{Si}$ contents close to the maximum of $8.0 \mathrm{apfu}$.

Albites were calculated assuming 8 oxygens and all have composition close to the pure sodic end-member. Stilpnomelane structural formulae were calculated assuming 24 oxygens and all $\mathrm{Fe}$ as divalent $\left(\mathrm{Fe}^{2+}\right)$. Stilpnomelanes have $\mathrm{Fe}$ amounts ranging from 1.86 to 2.91 apfu and $\mathrm{Mg}$ amounts ranging from 0.24 to 0.58 apfu (Table 2). For K-feldspar and biotite porphyroclasts, structural formulae were calculated 
Table 3. Representative microprobe analyses for K-Feldpars and albites which were calculated assuming 8 oxygens.

\begin{tabular}{|c|c|c|c|c|c|c|c|c|c|c|c|}
\hline Feldspar & KFeld & Kfeld & Kfeld & Kfeld & Kfeld & Albite & Kfeld & Kfeld & Albite & Kfeld & Kfeld \\
\hline \multicolumn{12}{|l|}{$\mathrm{Wt} \%$} \\
\hline $\mathrm{SiO} 2$ & 64.47 & 68.51 & 63.50 & 64.25 & 68.06 & 67.82 & 64.35 & 68.12 & 67.75 & 63.98 & 68.33 \\
\hline $\mathrm{TiO} 2$ & - & - & - & - & - & - & 0.02 & - & - & - & 0.07 \\
\hline $\mathrm{Al}_{2} \mathrm{O}_{3}$ & 18.75 & 20.33 & 18.32 & 18.66 & 20.50 & 19.84 & 18.28 & 19.43 & 20.20 & 18.91 & 20.43 \\
\hline $\mathrm{Cr}_{2} \mathrm{O}_{3}$ & - & - & - & - & - & - & - & - & - & - & - \\
\hline $\mathrm{FeO}$ & - & 0.15 & - & - & 0.13 & - & - & 0.27 & 0.09 & 0.11 & - \\
\hline $\mathrm{MnO}$ & - & - & - & - & - & - & 0.03 & - & - & - & 0.07 \\
\hline $\mathrm{MgO}$ & - & - & 0.04 & - & 0.04 & - & - & - & - & - & - \\
\hline $\mathrm{CaO}$ & - & - & - & - & - & 0.03 & - & - & - & - & - \\
\hline $\mathrm{Na}_{2} \mathrm{O}$ & 2.44 & 0.18 & 0.17 & 0.19 & 11.03 & 11.44 & - & 11.31 & 11.56 & 0.20 & 11.17 \\
\hline $\mathrm{K}_{2} \mathrm{O}$ & 13.48 & 9.05 & 16.32 & 14.72 & 0.28 & 0.05 & 15.74 & 0.16 & 0.04 & 14.39 & 0.56 \\
\hline TOT & 99.14 & 98.22 & 98.35 & 97.82 & 100.04 & 99.18 & 98.42 & 99.29 & 99.64 & 97.59 & 100.63 \\
\hline \multicolumn{12}{|l|}{ Cations } \\
\hline $\mathrm{Si}$ & 11.92 & 12.25 & 11.95 & 12.02 & 11.88 & 11.93 & 12.03 & 11.99 & 11.88 & 11.98 & 11.88 \\
\hline $\mathrm{Al}$ & 4.09 & 4.28 & 4.06 & 4.11 & 4.22 & 4.11 & 4.03 & 4.03 & 4.17 & 4.17 & 4.18 \\
\hline Sum Z & 16.01 & 16.53 & 16.02 & 16.13 & 16.09 & 16.05 & 16.06 & 16.01 & 16.05 & 16.16 & 16.06 \\
\hline $\mathrm{Fe}_{3}^{+}$ & 0.00 & 0.00 & 0.00 & 0.00 & 0.00 & 0.00 & 0.00 & 0.00 & 0.00 & 0.00 & 0.00 \\
\hline $\mathrm{Fe}_{2}^{+}$ & 0.00 & 0.02 & 0.00 & 0.00 & 0.02 & 0.00 & 0.00 & 0.04 & 0.01 & 0.02 & 0.00 \\
\hline $\mathrm{Mg}$ & 0.00 & 0.00 & 0.01 & 0.00 & 0.01 & 0.00 & 0.00 & 0.00 & 0.00 & 0.00 & 0.00 \\
\hline $\mathrm{Ca}$ & 0.00 & 0.00 & 0.00 & 0.00 & 0.00 & 0.01 & 0.00 & 0.00 & 0.00 & 0.00 & 0.00 \\
\hline $\mathrm{Na}$ & 0.87 & 0.06 & 0.06 & 0.07 & 3.73 & 3.90 & 0.00 & 3.86 & 3.93 & 0.07 & 3.76 \\
\hline K & 3.18 & 2.06 & 3.92 & 3.51 & 0.06 & 0.01 & 3.75 & 0.04 & 0.01 & 3.44 & 0.12 \\
\hline Sum X & 4.05 & 2.15 & 3.99 & 3.58 & 3.82 & 3.92 & 3.75 & 3.93 & 3.95 & 3.53 & 3.89 \\
\hline TOT & 20.06 & 18.68 & 20.01 & 19.71 & 19.91 & 19.97 & 19.82 & 19.95 & 20.00 & 19.68 & 19.95 \\
\hline$\% \mathrm{Ab}$ & 21.58 & 2.93 & 1.56 & 1.92 & 98.36 & 99.57 & 0.00 & 99.08 & 99.77 & 2.07 & 96.81 \\
\hline$\% \mathrm{An}$ & 0.00 & 0.00 & 0.00 & 0.00 & 0.00 & 0.14 & 0.00 & 0.00 & 0.00 & 0.00 & 0.00 \\
\hline$\%$ Or & 78.42 & 97.07 & 98.44 & 98.08 & 1.64 & 0.29 & 100.00 & 0.92 & 0.23 & 97.93 & 3.19 \\
\hline
\end{tabular}

assuming 8 and 22 oxygens respectively. The analysed Kfeldspars have composition close to the orthoclase pure endmember, with minor amounts of $\mathrm{Na}$ (Table 3).

The peak metamorphic mineral assemblage is defined by $\mathrm{Na}$ amphibole + phengite + quartz + albite + stilpnomelane. $\mathrm{Na}$ amphibole is a typical mineral of the blueschist facies and is indicative of HP/LT gradient metamorphism (e.g. Evans, 1990; Schiffman and Day, 1999, and references therein). The minimum temperature $(T)$ and pressure $(P)$ conditions of this mineral assemblage can be estimated using the reaction curves proposed by Schiffman and Day (1999) for the appearance of $\mathrm{Na}$ amphibole (stability field of the blueschist facies); the maximum temperature $(T)$ conditions were instead constrained by the presence of stilpnomelane, as shown by the following equilibrium: $\mathrm{Stp}+\mathrm{Phe}=\mathrm{Bt}+\mathrm{Chl}+\mathrm{Qtz}+\mathrm{W}$ (Massonne and Szpurka, 1997). Summing up all the available thermobarometric information, the metamorphic conditions can be estimated as temperature $(T)$ around $320 \pm 50^{\circ} \mathrm{C}$ and pressure $(P)$ greater than $0.70 \mathrm{GPa}$ (Fig. $4 \mathrm{c}$ ), consistent with those reported by
Malasoma et al. (2006) in metagranitic rocks from the area of our studied sample.

\section{EBSD data}

EBSD analysis of quartz was conducted with a Jeol 7001 FEG-SEM equipped with a NordlysMax EBSD detector (Oxford Instruments) at the Plymouth University Electron Microscopy Centre. Working conditions during acquisition of the EBSD patterns were $20 \mathrm{kV}, 70^{\circ}$ sample tilt, and high vacuum. Thin sections were chemically polished with colloidal silica and carbon-coated before the analysis. EBSD patterns were acquired on rectangular grids with step size of 1 and $2 \mu \mathrm{m}$. EBSD patterns were acquired and indexed with the AZtec software and processed with Channel 5 software (Oxford Instruments). Raw EBSD data were processed to reduce data noise following the procedure tested by Prior et al. (2002) and Bestmann and Prior (2003). EBSD results are shown in form of an inverse pole figure map, pole figures (equal angle, lower hemisphere) of crystallographic axes and 

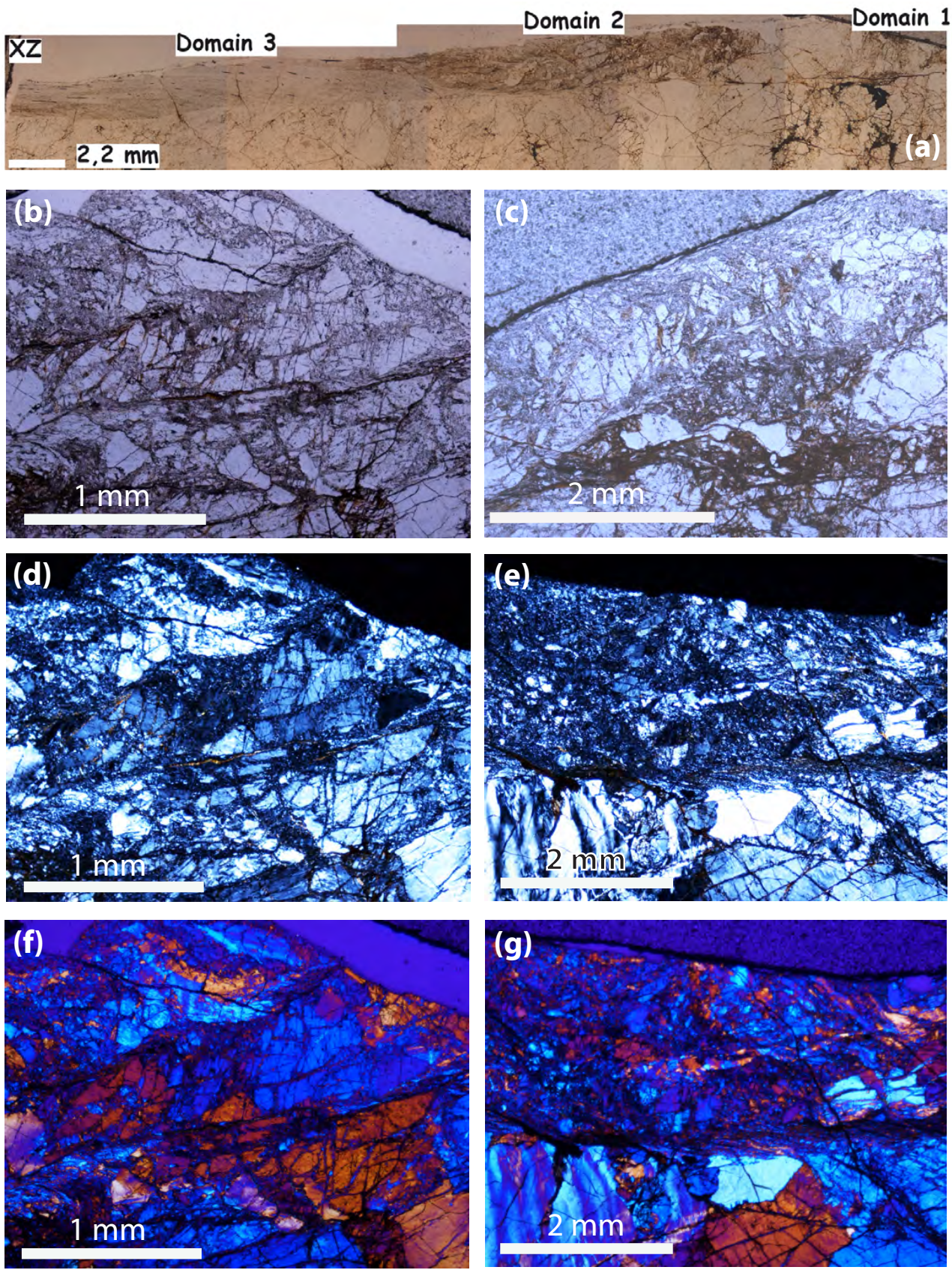

Figure 5. (a) Microscopic view of millimetre-scale shear zone nucleated after brittle precursor, with indication of the structuralcompositional domains within the shear zone. Domain 1: relict domain of cataclasite; Domain 2: foliated-cataclasite/phyllonite; Domain 3: ultramylonite. (b-g) Micrographs showing details of cataclastic relicts in Domain 1; (b, c, d) crush microbreccia showing angular to subangular quartz and feldspars clasts with intergranular and intragranular microfractures. Stilpnomelane is observable in (c) as filling microfractures. In (d) clasts of quartz and feldspars show relict internal deformations similar to those of the host protomylonite. (e) Protocataclasite with submillimetre-sized quartz and feldspar clasts within a fine-grained matrix. (f, g) Cataclasite with quartz and feldspar clasts in fine-grained matrix. The angular fragments and their grain size distribution are indicative of brittle comminution. (a, b, e) Images with plane-polarized light, (d, f) cross-polarized light, and (d, $\mathbf{g})$ cross-polarized with a lambda plate.

planes $(\langle 0001\rangle c$ axis, $\langle 11-20\rangle a$ axis, $\{10-10\}$ prism $\{m\}$, $\{10-11\}$ positive rhomb $\{r\},\{01-11\}$ negative rhomb $\{z\})$, misorientation profiles, and plots of misorientation axis in sample coordinates. 

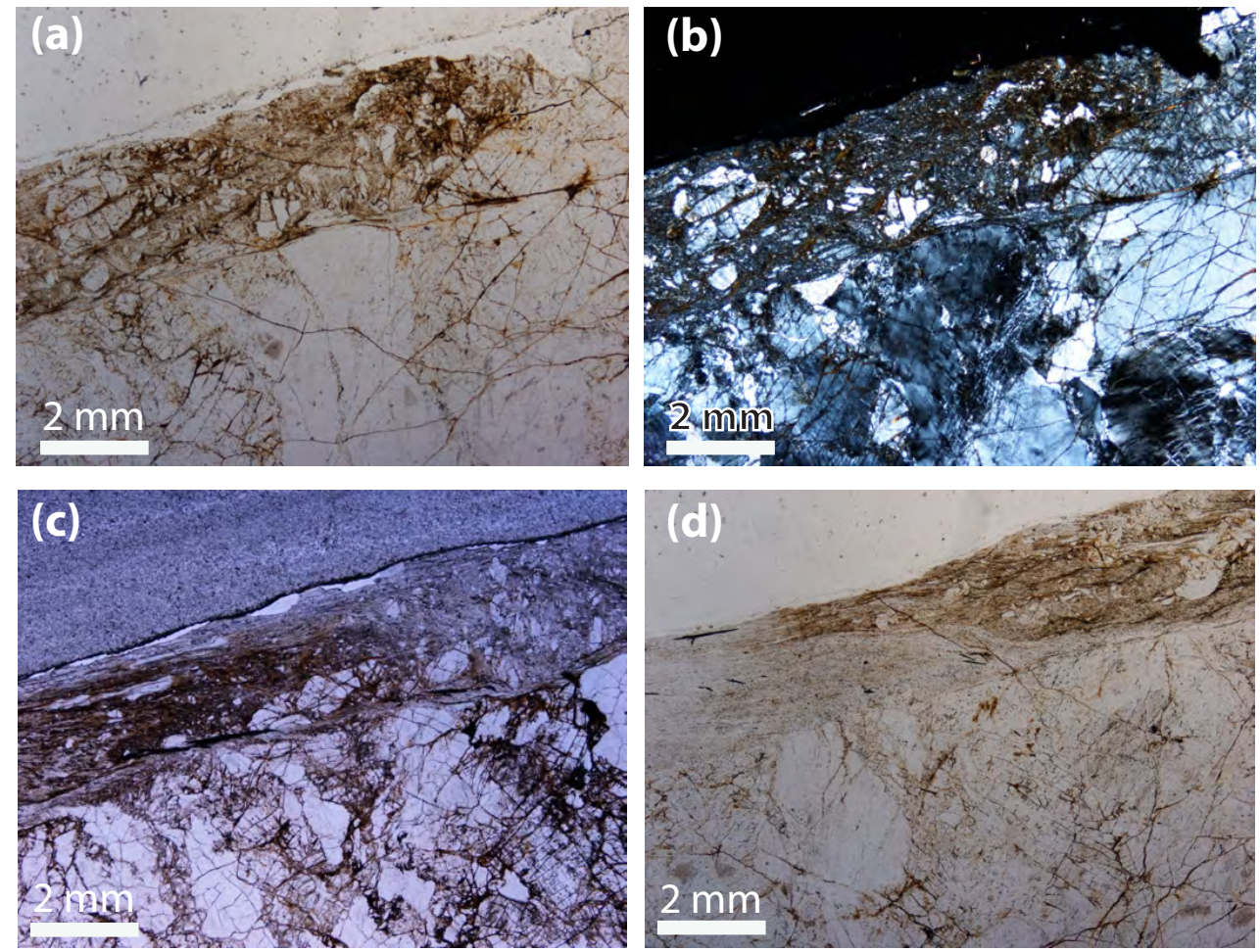

Figure 6. Micrographs showing details of foliated cataclasite/phyllonite of Domain 2 (a); (b) quartz and feldspar clasts are embedded in phyllosilicate-rich matrix defining sub-millimetre-spaced bands in Riedel $\left(R^{\prime} / C^{\prime}\right)$ orientation with respect to shear zone boundary. In (a) and (b) the subangular to subrounded shape of clasts and their grain size distribution due to brittle comminution are evident; (c) cataclasite to phyllonite transition and (d) foliated cataclasite to ultramylonite transition. (a, c, d) Plane-polarized light; (b) cross-polarized light.

\subsection{Quartz in the host rock}

We analysed a monocrystalline quartz ribbon elongated parallel to the host-rock foliation and sharply cut by the thin localized shear zone. The quartz ribbon contains two nearly orthogonal sets of intracrystalline shear bands of recrystallized grains (Fig. 8a). These are defined by the presence of a SPO oblique to the shear bands boundaries and by the $c$ axis orientation of the grains within the shear bands. SPO and crystallographic preferred orientation (CPO) in the bands are consistent with the kinematic framework of the protomylonitic host rock (see below). One set of shear band is oriented at a high angle $\left(90^{\circ} \pm 20\right.$, set 1$)$ and one at a low angle $\left(\leq 20^{\circ}\right.$, set 2$)$ to the host rock foliation (vertical in Fig. 8a). The average grain size of the recrystallized grains is $5 \pm 2 \mu \mathrm{m}$. The host grain also contains fine localized extinction bands (up to $20 \mu \mathrm{m}$ thick) (LEBs: Derez et al., 2015) subparallel to the bands of recrystallized grains. Low-angle boundaries are ubiquitous in the ribbon; on EBSD maps they are typically straight, poorly connected, and subparallel to the bands of recrystallized grains (Fig. 8b). Some low-angle boundaries are connected to form subgrains of approximately the same size of the recrystallized grains. Subgrains occur with a higher frequency at the intersection between two sets of recrystallized bands, and in regions sandwiched between closely spaced $(\leq 100 \mu \mathrm{m})$ subparallel bands of recrystallized grains (Fig. 8b).

The $c$ axis of the host ribbon grain is oriented near the pole to the host-rock foliation, i.e. in a position suitably oriented for the activation of the basal $\langle a\rangle$ slip system of quartz (Fig. 9a). The $c$-axis orientation of the recrystallized grains in the intracrystalline bands is mostly spread out along the periphery of the pole figure, although some scattered grains have their $c$ axis in intermediate positions between the $X$ and $Y$ directions of the pole figures (Fig. 9b). Such an orientation suggests that the recrystallized grains have experienced a rotation around the $Y$ direction of finite strain (i.e. centre of the pole figure) from the host-grain orientation (e.g. Van Daalen et al., 1999; Menegon et al., 2011).

This is confirmed by the boundary trace analysis (Prior et al., 2002; Menegon et al., 2010) of the two main sets of straight low-angle boundaries defining localized extinction bands (parallel to bands of recrystallized grains), one running ENE-WSW (subset 1) and one running ca. N-S (subset 2) in Fig. 8b. The dispersion paths of crystallographic directions in the pole figures of subset 1 (Fig. 9c) identifies $\{m\}$ as the rotation axis, which lies very close to the centre of the pole figure. The pole to the prismatic plane $\{m\}$ is the rotation axis associated with the basal $\{a\}$ and with the $\{a\}\langle c\rangle$ 

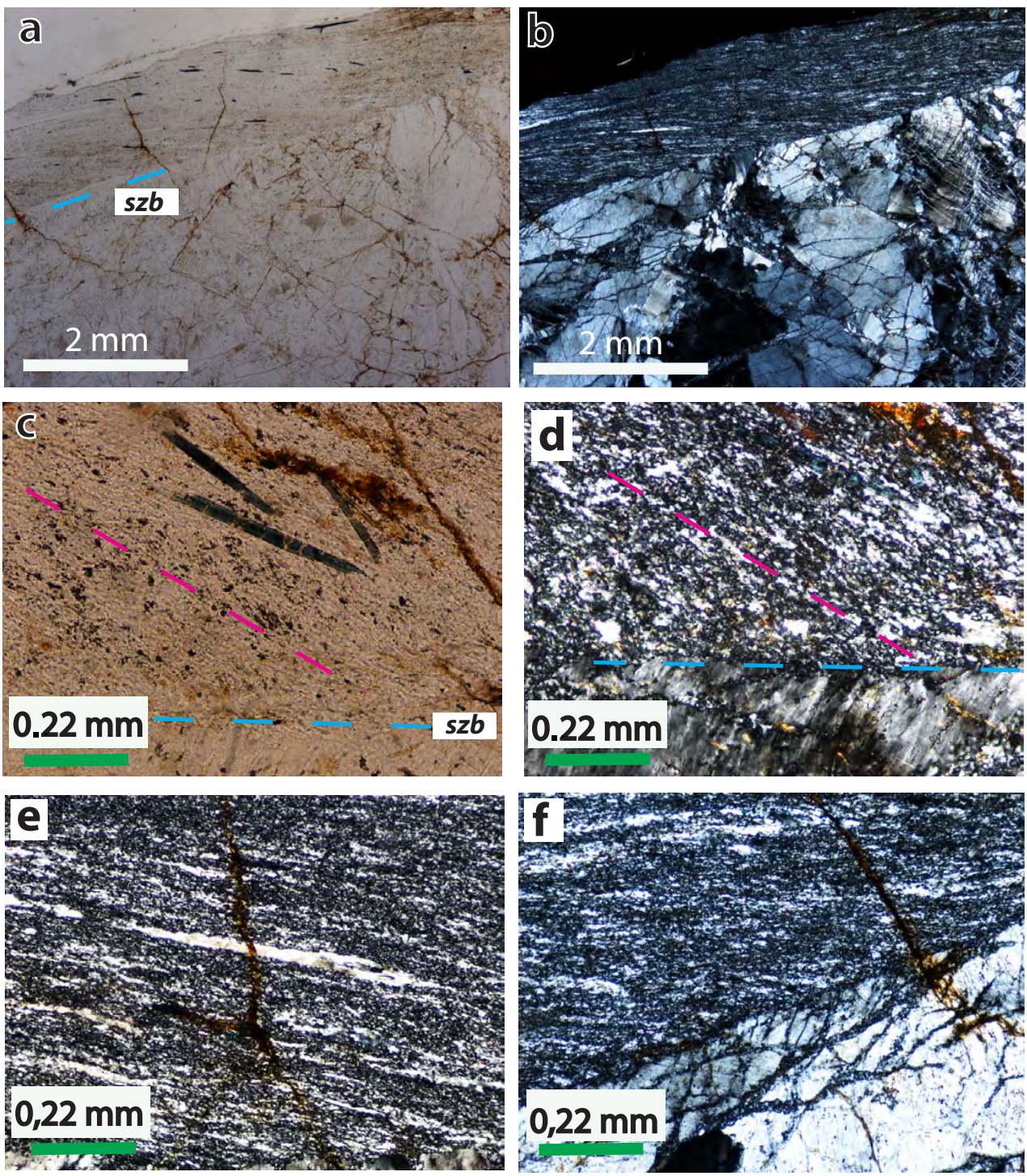

Figure 7. Microscopic view of ultramylonite. (a, b) Detail of ultramylonite and host protomylonite with the sharp shear zone boundary (szb) heritage of former host-fracture contact: (c) synkinematic Na amphibole, boudinaged within the quartz and albite ultramylonite matrix. Red dashed line (see also in $\mathbf{d}$ ) indicates the shape preferred orientation of the quartz and albite matrix, whereas in blue the shear zone boundary (szb) is indicated; (d) quartz and albite recrystallized matrix, in the lower part the boundary (blue dashed line) of microscale shear zone to a host quartz porphyroclast. (e) Quartz ribbon with a strong elongation (1:15, $X / Z$ ratio) defining a shape preferred orientation oblique (15 $\left.{ }^{\circ}\right)$ to the shear zone boundary (see $\mathbf{b}$ for location of quartz ribbon within the shear zone). (f) Detail of shear zone boundary showing intragranular fractures in the host protomylonite showing Riedel geometry. Along the Riedel shear, former cataclastic fragments recrystallized to produce the fine $(5-10 \mu \mathrm{m}$ in size $)$ new grains.

slip system in quartz (e.g. Neumann, 2000), and, accordingly, subset 1 can be interpreted as a tilt boundary plane produced by the activity of the slip system basal $\langle a\rangle$ (Fig. 9c) and containing the boundary trace of subset 1 and the rotation axis.

Subset 2 has a similar dispersion path as subset 1, with $\{m\}$ as the identified rotation axis. However, in this case the boundary trace analysis is not consistent with a tilt boundary produced by the activity of the slip system basal $\{a\}$, but could indicate the activity of the $\{a\}\langle c\rangle$ slip system
(Fig. 9d). However, activity of $c$ slip in quartz typically requires temperature in excess of $600^{\circ} \mathrm{C}$ (Kruhl, 1996; Zibra et al., 2010) and, therefore, appears unlikely in our samples. Moreover, misorientation profiles across low-angle boundaries with a subset 2 orientation show abrupt misorientation jumps of up to $6^{\circ}$ (profiles c-d in Figs. $8 \mathrm{~b}$ and 9e), as opposed to a gradual accumulation of misorientation towards low-angle boundaries with a subset 1 orientation (profile $\mathrm{a}-\mathrm{b}$ in Figs. $8 \mathrm{~b}$ and 9c). Thus, the low-angle boundaries with a 

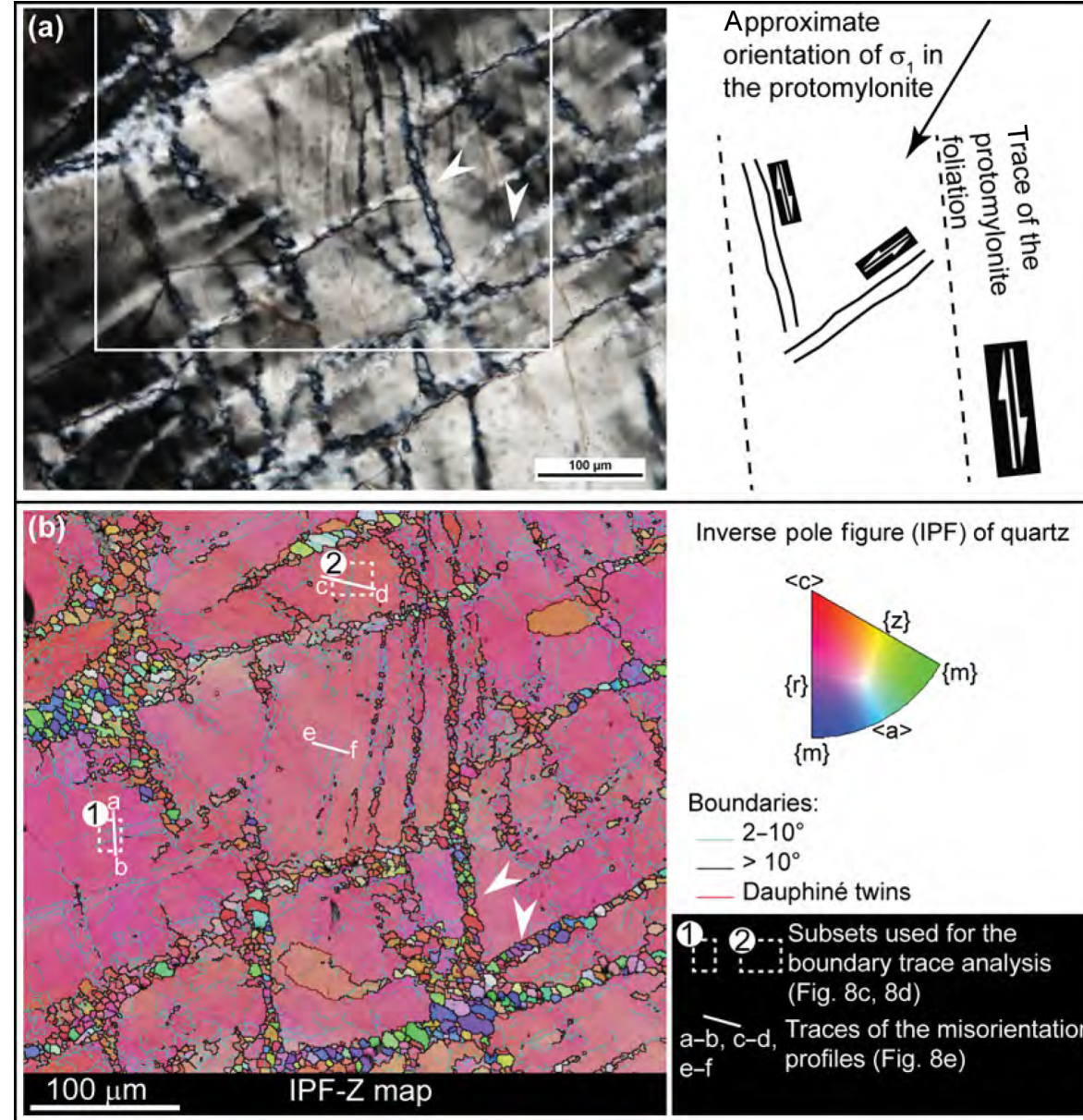

Inverse pole figure (IPF) of quartz

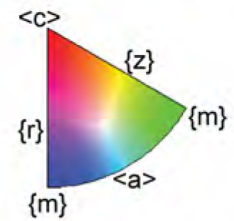

Boundaries:

$2-10^{\circ}$

$\longrightarrow 10^{\circ}$

_ Dauphiné twins

1. . 2... Subsets used for the

:...... boundary trace analysis

(Fig. 8c, 8d)

a-b, $-d$, Traces of the misorientation

e-f profiles (Fig. 8e)

Figure 8. EBSD analysis of quartz in the host protomylonite. (a) Microstructure of the analysed site. The white arrows in (a) and (b) indicate the same pair of conjugate shear. (b) Inverse pole figure map with the respect to the protomylonitic foliation in the host rock (vertical in the figure). Location of subset 1 and 2 and trace of misorientation profiles (a)-(b), (c)-(d), and (e)-(f) are shown.

subset 2 orientation could represent microcracks subparallel to the basal planes (e.g. Kjøll et al., 2015) that localized rigid body rotation of fragments around the $Y$ direction (e.g. Trepmann et al., 2007; Menegon et al., 2013). The rotation around $Y$ of (1) the crystallographic directions of the host grain and (2) the recrystallized grains (in this case for large misorientation $>10^{\circ}$ ) is confirmed by the plots of the misorientation axis in sample coordinates (Fig. 9f).

\subsection{Quartz in the ultramylonite}

We analysed polycrystalline ribbons of recrystallized grains from domain 3 of the localized shear zone (Fig. 10a). The $c$-axis orientation of the recrystallized grains defines an inclined type I crossed girdle synthetically oriented with respect to the bulk shear sense of the shear zone (Fig. 10b). The $c$-axes are preferentially clustered near the pole to the shear zone boundary, i.e. in an orientation suitably oriented for the activity of the basal $\langle a\rangle$ slip system. The average grain size of the recrystallized grains in domain 3 is $6 \pm 2 \mu \mathrm{m}$.

\section{Ultramylonite: palaeopiezometry, flow stress, and strain rate}

The microstructure and the crystallographic preferred orientation of quartz in the ultramylonite indicate that quartz deformed by dislocation creep and recrystallized to a finegrained aggregate. Thus, the rheology and the flow stress in the ultramylonite can be evaluated extrapolating experimentally calibrated flow laws of quartz to the deformation conditions.

The rheology of quartz deforming by dislocation creep is generally described in terms of a power-law equation:

$\dot{\varepsilon}=A f_{\mathrm{H}_{2} \mathrm{O}}^{m} e^{(-Q / R T)} \sigma^{n}$,

where $\dot{\varepsilon}$ is the strain rate, $f_{\mathrm{H}_{2} \mathrm{O}}$ is the water fugacity (raised to the power of $m), Q$ is the activation energy, $R$ is the universal gas constant, $T$ is the temperature, $\sigma$ is the differential stress, and $n$ is the stress exponent. We used the theoretical dislocation creep flow law of Hirth et al. (2001), which has derived a linear dependence of strain rate on the water fu- 


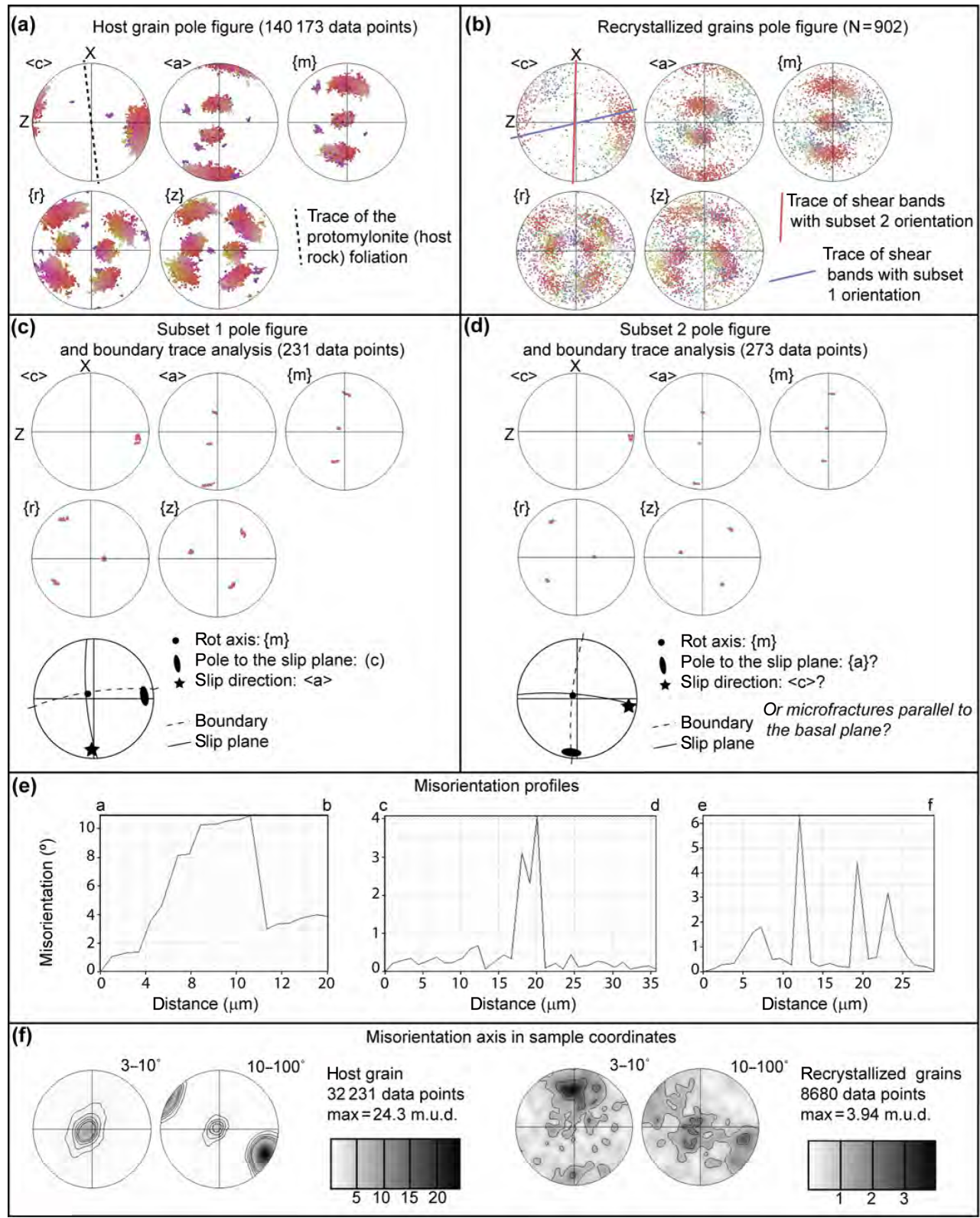

Figure 9. EBSD analysis of quartz in the host protomylonite. (a) Pole figure of the host grain, colour-coded per the quartz inverse pole figure with respect to the protomylonitic foliation shown in Fig. 8b. (b) Pole figure of recrystallized quartz in the intracrystalline bands. The blue and red line indicates the average orientation of the trace of the intracrystalline bands with a subset 1 and 2 orientation, respectively. (c) Boundary trace analysis of the localized extinction band of subset 1. (d) Boundary trace analysis of the localized extinction band of subset 2. (e) Point-to-point misorientation profiles. See Fig. $8 \mathrm{~b}$ for location of the traces of the profiles. (f) Misorientation axis of the host grain and of the recrystallized grains in sample coordinates.

gacity $(m=1)$ and a stress exponent of 4 . A water fugacity of $172 \mathrm{MPa}$ is calculated from the water fugacity coefficient reported in Tödheide (1972) at $T=350^{\circ} \mathrm{C}, P=0.8 \mathrm{GPa}$.

The palaeostress (assuming steady-state flow at the time of viscous deformation) can be determined by means of a recrystallized quartz grain size palaeopiezometer (e.g. Stipp and Tullis, 2003), which has been calibrated in the form $\Delta \sigma=B D^{-x}$, where $\Delta \sigma$ is the steady-state differential stress $\left(\sigma_{1}-\sigma_{3}\right), D$ is the recrystallized grain size, and $B$ and $X$ are empirical constants. Using the recrystallized grain size piezometer of quartz calibrated by Stipp and Tullis (2003), a recrystallized grain size of 5-10 $\mu \mathrm{m}$ indicates differential stress in the range of 110-190 MPa. Extrapolation of the flow law of Hirth et al. (2001) yields a strain rate in the range of $7.6 \times 10^{-13}-6.2 \times 10^{-12} \mathrm{~s}^{-1}$ in the ultramylonite at the estimated deformation temperature of ca. $300^{\circ} \mathrm{C}$. 

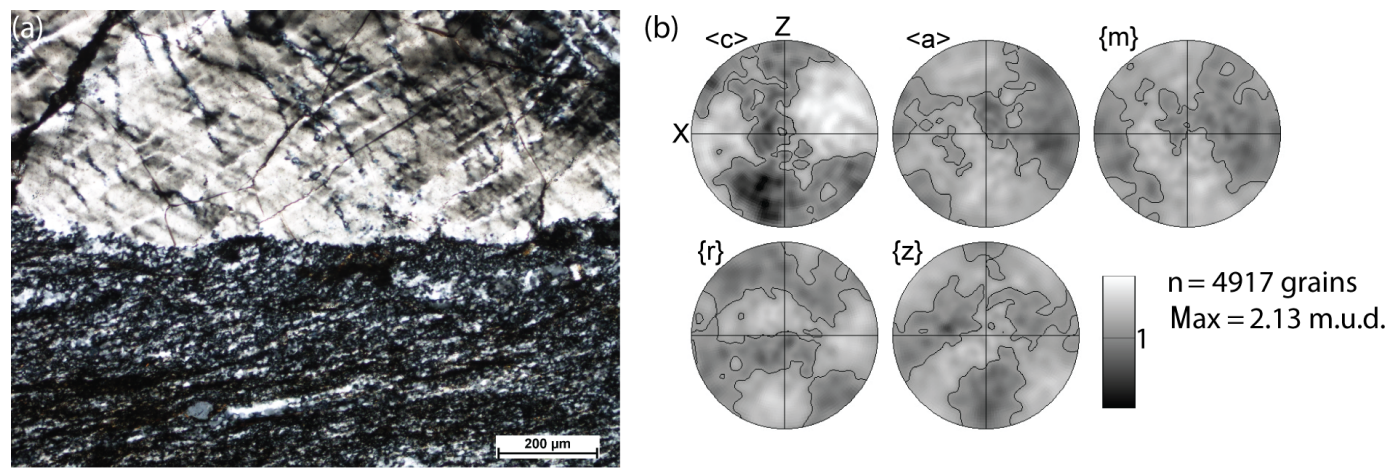

Figure 10. EBSD analysis of quartz in the ultramylonite. (a) Microstructure of the recrystallized quartz from domain 3 in the ultramylonite. (b) Pole figure of recrystallized quartz grains from (a). Only grains from recrystallized aggregates in the ultramylonite were analysed.

\section{Discussion and conclusion}

\subsection{Kinematic framework and deformation mechanisms of the host-protomylonite}

On the basis of overprinting relationships we may infer that the oldest deformation fabric of our analysed sample is represented by the subvertical protomylonite foliation (Fig. 2), which shows microstructural features described in the text. This fabric type and the associated deformation microstructures represent a ubiquitous regional feature in the Popolasca granitoids and is not restricted to our studied sample only.

The $c$-axis maximum of the quartz ribbon in the host protomylonite is oriented near the pole of the protomylonite foliation and rotated clockwise to indicate a dextral sense of shear in the protomylonite (Fig. 9a). The dextral sense of shear corresponds to the regional top-to-the-west sense of shear observed in the field. The $c$-axis orientations of grains in the bands differ from the orientations of the host grains, as shown by our EBSD analysis (Fig. 9a, b). This difference is consistent with the relative rotation of the $c$ axes of grains in the conjugate bands, reflecting their respective sense of shear assuming a shortening direction oriented approximately NESW in Fig. 8a, and consistent with the bulk dextral sense of shear of the protomylonite. In this kinematic framework, the respective sense of shear is dextral in bands with a subset 2 orientation and sinistral in bands with a subset 1 orientation (Fig. 8a). The SPO in the bands is also consistent with their respective sense of shear. Thus, we conclude that (1) the intracrystalline bands of recrystallized grains are conjugate shear bands; (2) they formed during the development of the regional proto-mylonitic foliation of the unit, and not in response to the localized brittle event investigated in the present study, and can therefore be used to evaluate the stress conditions in the protomylonite prior to the brittle event; and (3) they were overprinted by the cataclastic event forming the brittle precursor of the ultramylonite in our sample (Fig. 5f, g).
The microstructure and the trace analysis of low-angle boundaries indicates that deformation mechanisms in quartz in the host-protomylonite result from a combination of microfracturing and low-temperature dislocation activity (Fig. 9c, d). Although factors like the initial aperture of the (micro)cracks and the starting grain size of potential micro-gauge fragments can control the initial grain size in the quartz bands, the final microstructure of quartz in the bands is not cataclastic, but typical of a dynamic recrystallization aggregate with a clear SPO and CPO. Accordingly, our EBSD analysis suggests that the quartz grains in the intracrystalline bands deformed by dislocation creep on the basal $\langle a\rangle$ slip system. This is consistent with a microstructural evolution where dislocation creep overprinted fracturing and neocrystallization along cracks (e.g. Trepmann et al., 2007, 2017). Along cracks, new grains grew by straininduced grain boundary migration from fractured fragments with a low dislocation density (e.g. Trepmann et al., 2007) and deformed by dislocation creep on the dominant basal $\langle a\rangle$ slip system, as shown by their CPO and SPO.

In conclusion, our observations suggest that the final grain size in the intracrystalline bands represents an equilibrium grain size with the flow stress during crystal-plastic flow of quartz in the bands. Thus, they can be used to evaluate the differential stress during dislocation creep deformation in the protomylonite before the development of the brittle precursor as developed furthermore below.

\subsection{Viscous-brittle-viscous deformation under HP/LT conditions}

The analysed example documents a switch in deformation mode and mechanisms within an HP/LT fault zone. Overprinting relationships and microstructural features suggest the following deformation sequence: stage (1) consists of distributed deformation (at a regional to sample scale) and development of a protomylonitic foliation in the granitoid by quartz low-temperature plasticity, microfracturing, and albite neo-crystallization from K-feldspar porphyroclasts (Fitzger- 
ald and Stünitz, 1993); this was followed by stage (2), in which localized deformation by brittle fracturing formed a millimetre-thick cataclasite, which acted as a precursor for stage (3) localization of viscous deformation and ultramylonite development. The synkinematic and post-kinematic growth of $\mathrm{Na}$ amphibole in the host rock foliation and in localized ultramylonite indicates that the entire deformation sequence occurred under $\mathrm{HP} / \mathrm{LT}$ conditions (ca. $300^{\circ} \mathrm{C}$ at $\geq 0.7 \mathrm{GPa}$ ), corresponding to a depth of $23-30 \mathrm{~km}$ in the subduction channel.

The estimated $P-T$ conditions are consistent with a low$T$ plasticity regime in quartz (Stipp et al., 2002; Derez et al., 2015, and references therein). Accordingly, the deformation microstructures of quartz produced during stage (1) in the host rock appear to be the product of the competition between dislocation activity and fracturing. Localized extinction bands at a high angle to the host rock foliation (subset 1 in Fig. 8b) are consistent with the activity of the basal $\langle a\rangle$ slip system, whereas localized extinction bands subparallel to the host-rock foliation (subset 2 in Fig. 8b) are interpreted as fractures subparallel to the basal plane, as previously observed by Kjøll et al. (2015). Some localized extinction bands (especially those with a subset 2 orientation; see Fig. 8b) contain isolated small new grains that are considerably smaller than the average grain size in the recrystallized bands, and that are only slightly misoriented with respect to the host grain. Moreover, the high-angle boundaries in such localized extinction bands are not always fully connected to define entire new grains. Together with the abrupt misorientation jumps (Fig. 9e), these observations further suggest that localized extinction bands with a subset 2 orientation represent fractured domains in which the fragments have rotated passively and sealed together, as proposed by, for example, Derez et al. (2015).

In conjunction with the local fracturing of the host grain, deformation of the recrystallized grains in the conjugate intracrystalline bands involved dislocation activity, as indicated by the cluster of misorientation axis around the prism $\{m\}$ for low misorientations (compare Fig. 9f with 9a). This is consistent with the local activity of the basal $\{a\}$ slip system in the recrystallized bands, as also indicated by the CPO of the recrystallized grains in the shear bands (Fig. 9b).

The type-I crossed girdle $c$-axis CPO of quartz in the ultramylonite suggests the concomitant activity of basal $\langle a\rangle$, rhomb $\langle a\rangle$ and prims $\langle a\rangle$ slip systems in the recrystallized grains (Fig. 10). The grain size of recrystallized quartz in the ultramylonites is in the same range $(5-10 \mu \mathrm{m})$ as in the intracrystalline bands in the host rock. This suggests that 5-10 $\mu \mathrm{m}$ represents the equilibrium grain size for the flow stress (estimated in the range of 110-190 MPa with recrystallized grain size piezometry) during viscous deformation before and after the transient brittle event of stage (2).

During stage (2) the development of cataclasite and related dilatancy resulted in an increase in permeability and thus facilitated fluid access and fluid mobility in the shear zone. This enhanced mineral reactions as testified by modal enrichment of stilpnomelane (by biotite breakdown) and $\mathrm{Na}$ amphibole in the ultramylonite.

Therefore, the observed structures witness a change in deformation style (from sample-scale distributed to samplescale localized strain in brittle precursor), and a switch in the dominant deformation mechanism (from low $T$ plasticity in the host rock to cataclasis and back to crystal plasticity in the ultramylonite), which occurred at the footwall of the subduction interface under temperature conditions (ca. $300^{\circ} \mathrm{C}$ ) typical of the brittle-viscous transition in quartz-feldspathic rocks.

Finally, the transition from stage (2) and stage (3) is consistent with the general observation that nucleation of localized ductile shear zones requires, in some cases, the presence of a planar compositional or structural precursor (e.g. Pennacchioni and Zucchi, 2012, and references therein). The example from the Popolasca granite demonstrates that (i) nucleation on brittle precursors also occurs under HP/LT conditions in the subduction channel, and (ii) the brittle precursors are not necessarily inherited from an earlier deformation event, but can be the manifestation of switches in deformation mode in the footwall of the subduction interface.

\subsection{Significance of the switch in deformation mode and implications for fault-slip behaviours in subduction zones}

We interpreted the inferred deformation sequence and structures as the result of transient instabilities (Sibson, 1980; White, 1996; Handy and Brun, 2004), possibly representative of mixed fault-slip behaviours at seismogenic depth in the subduction channel. We have estimated the conditions resulting in the transient brittle event during stage (2) under the following assumptions and approximations:

1. The coefficient of internal friction, $\mu_{i}$, is generally between 0.5 and 1.0 in intact rocks (Sibson, 1985). We considered $\mu_{i}=0.6$ in the failure envelope for the intact Popolasca granitoid.

2. We used a cohesive strength of $35 \mathrm{MPa}$ as representative of granitoids (Amitrano and Schmittbuhl, 2002), with a resulting tensile strength of $17.5 \mathrm{MPa}$.

3. We assumed an Andersonian stress field and a thrusting regime. The effective vertical stress $\sigma_{v}^{\prime}$ corresponds to the effective minimum principal stress $\sigma_{3}^{\prime}=\sigma_{3}-P_{\mathrm{f}}$, where $P_{\mathrm{f}}$ is the pore fluid pressure. We considered a hydrostatic pore pressure $\left(\lambda=0.4, P_{\mathrm{f}}=320 \mathrm{MPa}\right.$ for $\sigma_{3}=800 \mathrm{MPa}$ ) during the formation of the protomylonite foliation in the host rock.

4. We assumed a differential stress of 110-190 MPa during viscous flow of the granitoid prior to brittle failure at $\sigma_{v}^{\prime}=480 \mathrm{MPa}$, as derived from the recrystallized grain size piezometry in the protomylonite. 

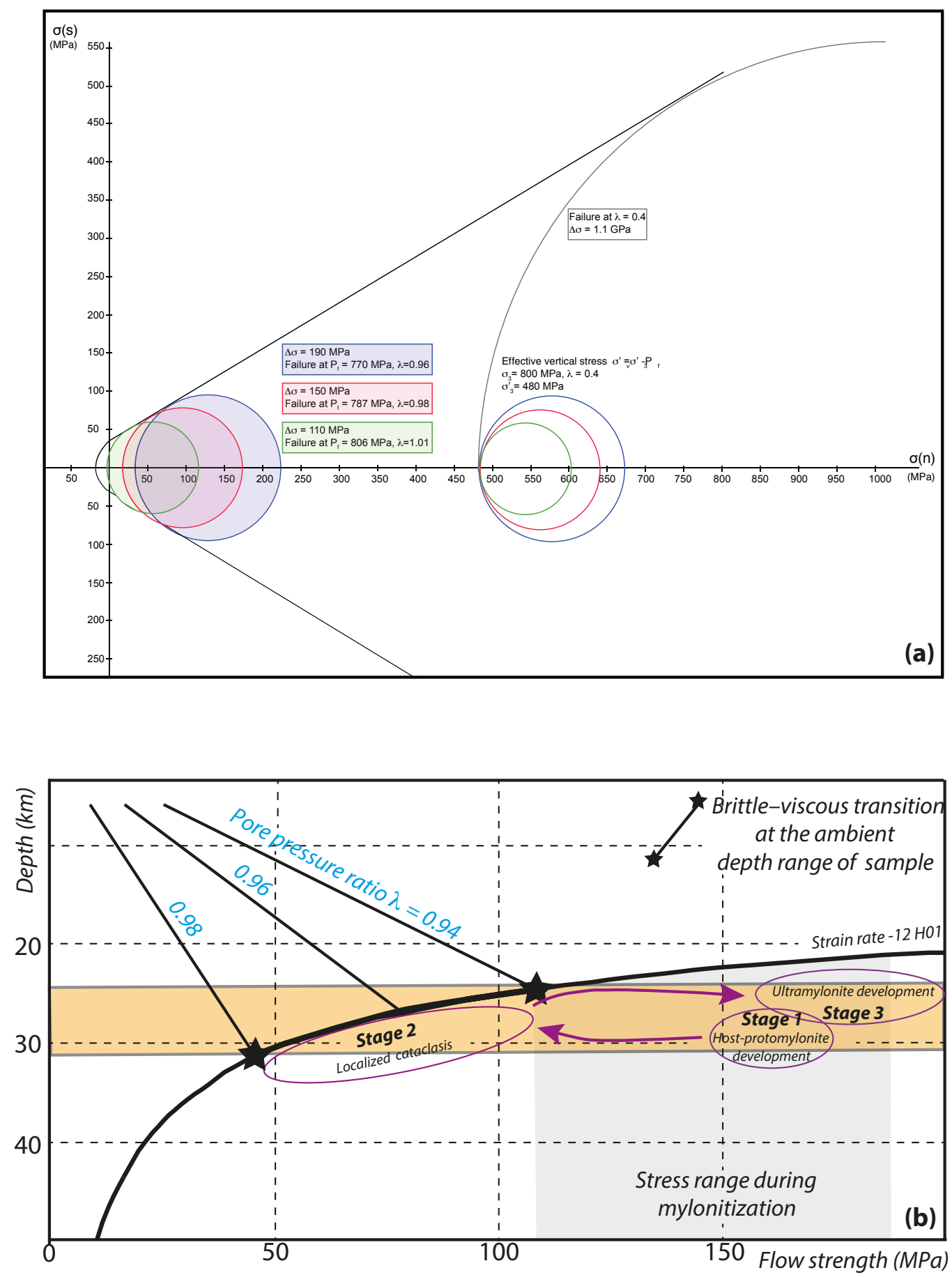

Figure 11. (a) Brittle failure analysis for our studied sample; see text for assumptions and approximations. For the differential stress range and the vertical stress considered, brittle failure requires (sub)lithostathic fluid pressure $(0.96<\lambda<1)$, whereas viscous deformation at the estimated depth range $(23-30 \mathrm{~km})$ is only possible for pore fluid pressure $\leq 0.94$. (b) Rheological profile calculated for a fixed strain rate of $10^{-12} \mathrm{~s}^{-1}$ (see text for calculation details) using the quartz flow law of Hirth et al. (2001). A cycle of switching in deformation style and mechanisms is suggested for the analysed sample in its ambient depth range. The frictional Byerlee envelope is calculated using an average friction coefficient of 0.7 for various pore fluid pressure ratio values (Fig. 11a and text). Stress estimates based on recrystallized quartz piezometry (grey shaded area) were calculated following Stipp and Tullis (2003). 


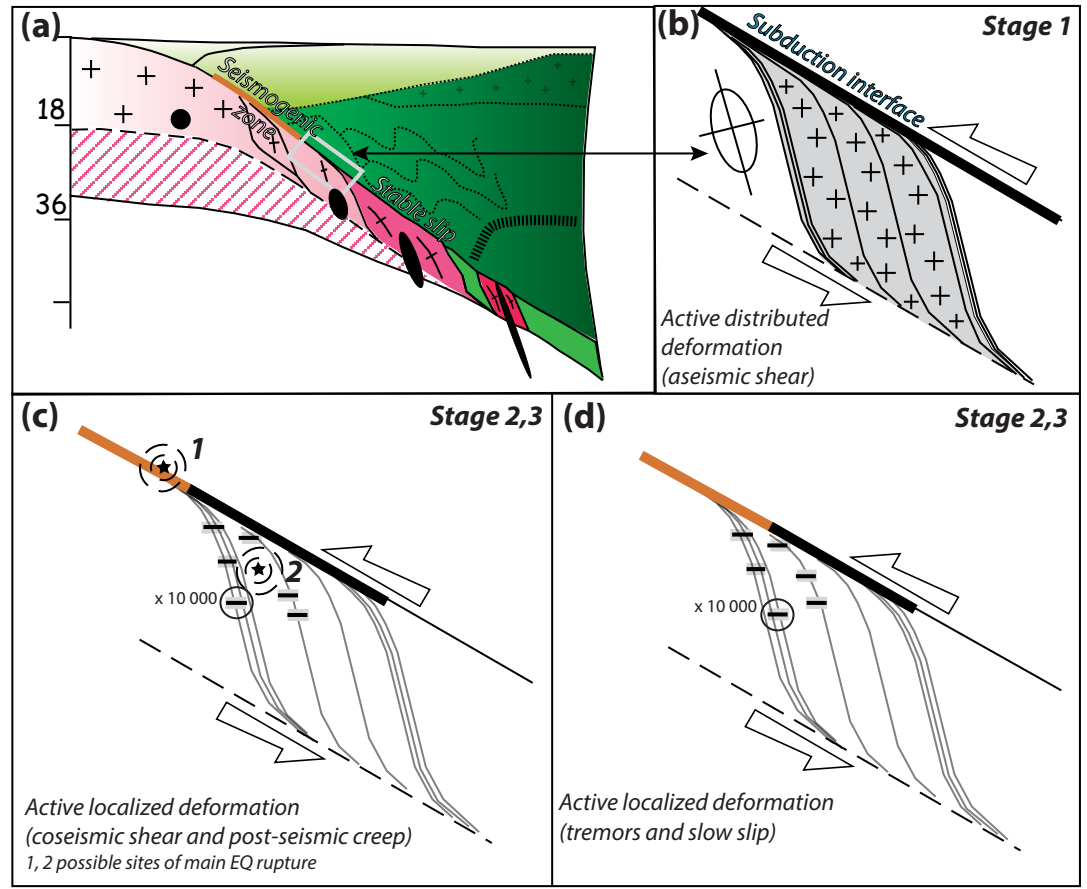

Figure 12. (a) Simplified model of the ancient subduction of the corsican continental crust, with indication where the mechanical coupling is the highest (seismogenic zone) and lowest (stable slip). The white rectangle corresponds to the inferred zone of the studied sample. The pink to red shading plots the lower to higher blueschist- to eclogite-facies peak metamorphism in continental-derived crustal units. (a, b, c, d) Multi-stage scenario for development of the association of granitic protomylonites and ultramylonites from brittle precursors in the Popolasca area: (a) general sketch showing the east-dipping ancient Alpine subduction of the corsican continental crust; (b) formation of a crustal-scale anastomosed network of shear zones within the host granitic crust and active distributed deformation with aseismic creep; (c) formation of brittle instabilities (stage 2) in the shear zone by seismic ruptures nucleated along (1) the subduction interface or (2) the core of granites and propagating across and beyond the granitic mylonites, followed by post-seismic creep, with localization of viscous shear zone after brittle precursor (stage 3); and (d) formation of brittle instabilities by seismic tremors and slow-slip events followed by post-seismic (post-tremors) creep.

The results of our analysis are shown in Fig. 11a. For brittle failure, it is necessary to invoke high differential stresses (of the order of $1.1 \mathrm{GPa}$ assuming a hydrostatic pore fluid pressure), or higher fluid pressure (Fig. 11a). Differential stresses in excess of $1 \mathrm{GPa}$ have been associated with intermediate depth $(50-300 \mathrm{~km})$ earthquakes in the subduction channel (e.g. John et al., 2009) and are expected to result in extensive development of pseudotachylytes in granitoid rocks (e.g. Austrheim, 2013, and references therein), which, however, have not been observed in the sample studied here.

For the differential stress range and the vertical stress considered here, brittle failure requires (sub)lithostathic fluid pressure $(0.96<\lambda<1$, Fig. 11). The strength envelope plotted for pore fluid pressure between 0.98 and 0.94 and for a strain rate of $10^{-12} \mathrm{~s}^{-1}$ (Fig. 11b) suggests that viscous deformation at the estimated depth range $(23-30 \mathrm{~km})$ is only possible for pore fluid pressure $\leq 0.94$; otherwise brittle deformation is expected to occur. Thus, under the assumptions listed above, our analysis indicates that local fluctuations in pore fluid pressure can explain the cyclic viscous-brittleviscous deformation switch. However, despite the synkine- matic growth of hydrous minerals in the cataclasite and the high pore fluid pressure required at failure, there is no evidence of macroscopic veining or hybrid fractures in the samples. Our analysis is consistent with this observation, in that failure occurs entirely in the shear fractures field and not in the (hybrid) shear extension fractures field (Fig. 11a).

Drawing from the results shown in Fig. 11a, b and using concepts and inferences coming from modern studies of convergent subduction system (e.g. Ozowa et al., 2002; Fu and Freymuller, 2013; Bedford et al., 2013), the following deformation scenario (Fig. 12) is envisaged. A first stage of distributed deformation (stage 1) may be associated with development of map-scale anastomosing shear zones (protomylonitic foliation at sample scale) during aseismic creep; subsequently, following Angiboust et al. (2015), two possible deformation scenarios and slip patterns may be envisaged: (a) propagation at seismic rate of microrupture followed by afterslip or (b) slow-slip phenomena in an aseismically creeping crust. In the first case, a transient strain rate increase associated with brittle fracturing would represent the deep response of the transition zone to a specific stage of the 
seismic cycle taking place higher up along the seismogenic portion of the subduction interface (Fig. 12c, scenario 1) or in less deformed domains acting as local stress raisers nearby (Fig. 12c, scenario 2). Cataclastic deformation would then correlate with coseismic to post-seismic deformation higher up along the interface. In that case, the mylonitization of the brittle precursor would be the record of subsequent interseismic deformation at lower strain rates, taking place in the time frame between two earthquakes.

In the second case (Fig. 12d), the transient highs in strain rates expressed by brittle fracturing and cataclasis could be the record of deformation associated with slow-slip events (SSEs) or other transient slips, generally localized along the subduction interface at this depth range itself (e.g. Shelly et al., 2006; Fagereng et al., 2014). We are aware that the mechanism(s) of SSEs initiation is still poorly understood, and that stress/strain rate perturbations triggered by an earthquake nearby followed by post-seismic slip and interseismic creep is an equally feasible mechanism to explain the deformation sequence recorded in our sample. However, our preferred interpretation is that the transient brittle deformation recorded in our studied sample is the manifestation of a slow-slip event, for the following reasons: (1) subduction interface SSEs typically occur at the downdip transition from stick-slip behaviour to aseismic creep (e.g. Wallace and Beavan, 2010), and, in granitoid rocks, this transition is expected to occur at the $T$ range of deformation of our case study, as witnessed by the deformation microstructures of quartz and feldspar in the host protomylonite, and (2) SSEs are often related to high pore fluid pressure (e.g. Liu and Rice, 2007).

Whatever the actual process triggering brittle deformation was, we want to emphasize that detailed microstructural studies of exhumed shear zones are a valuable complement to the geodetic, seismological, and experimental studies that aim to unravel the complex fault-slip behaviours at the subduction interface. In this context, our studied sample represents a new and still not yet documented case study of brittleviscous transition zone and processes in subducted continental crust. Moreover, our study reinforces the concept that the external zones of Alpine Corsica represent a unique target to document and better understand footwall deformation structures and processes related to HP/LT continental subduction.

Data availability. Original data underlying the material presented are available by contacting the authors.

Competing interests. The authors declare that they have no conflict of interest.

Special issue statement. This article is part of the special issue "Analysis of deformation microstructures and mechanisms on all scales". It is a result of the EGU General Assembly 2016, Vienna, Austria, 17-22 April 2016.

Acknowledgements. This work was developed and funded by the Italian PRIN 2006 project. Luca Menegon acknowledges financial support from a FP7 Marie Curie Career Integration Grant (grant agreement PCIG13-GA-2013-618289). The staff at the Plymouth University Electron Microscopy Centre are thanked for support during EBSD analysis. Constructive reviews by Giulio Viola and of an anonymous reviewer significantly improved the manuscript and are greatly acknowledged, as well as the final anonymous peer reviewer. Editorial handling of the special issue by Renée Heilbronner, Rüdiger Kilian, Florian Fusseis, and Ilka Weikusat is also greatly acknowledged.

Edited by: Renée Heilbronner

Reviewed by: Giulio Viola and one anonymous referee

\section{References}

Altenberger, U., Prosser, G., Grande, A., Günter, C., and Langone, A.: A seismogenic zone in the deep crust indicated by pseudotachylytes and ultramylonites in granulite-facies ricks of Calabria (Southern Italy), Contrib. Mineral. Petr., 166, 975-994, 2013.

Amitrano, D. and Schmittbuhl, J.: Fracture roughness and gouge distribution of a granite shear band, J. Geophys. Res., 107, 1-16, https://doi.org/10.1029/2002JB001761, 2002.

Andersen, T. B. and Austrheim, H.: Fossil earthquakes recorded by pseudotachylytes in mantle peridotites from the Alpine subduction complex of Corsica, Earth Planet. Sc. Lett., 242, 58-72, 2006.

Andersen, T. B., Austrheim, H., Deseta, N., Silkoset, P., and Ashwal, L. D.: Large subduction earthquakes along the fossil Moho in Alpine Corsica, Geology, 42, 395-398, https://doi.org/10.1130/G35345.1, 2014.

Angiboust, S., Glodny, J., Oncken, O., and Chopin, C.: In search of transient subduction interfaces in the Dent Blanche-Sesia Tectonic System (W. Alps), Lithos, 205, 298-321, 2014.

Angiboust, S., Kirsch, J., Oncken, O., Glodny, J., Monié, P., and Rybacki, E.: Probing the transition between seismically coupled and decoupled segments along an ancient subduction interface, Geochem. Geophys. Geosys., 16, 1905-1922, https://doi.org/10.1002/2015GC005776, 2015.

Atkinson, B. K.: Subcritical crack propagation in rocks: theory, experimental result and applications, J. Struct. Geol., 4, 41-56, 1982.

Austrheim, H.: Fluid and deformation induced metamorphic processes around Moho beneath continent collision zones: Examples from the exposed root zone of the Caledonian mountain belt, W-Norway, Tectonophysics, 609, 620-635, 2013.

Austrheim, H. and Andersen T. B.: Pseudotachylytes from Corsica: fossil earthquakes from a subduction complex, Terra Nova, 16, 193-197, 2004.

Austrheim, H. and Boundy, T. M.: Pseudotachylytes generated during seismic faulting and eclogitization of the deep crust, Science, 265, 82-83, 1994. 
Beaudoin, A., Augier, R., Joilivet, L., Jourdon, A., Raimbourg, H., Scaillet, S., and Cardello, G. L.: Deformation behavior of continentala crust during subduction and exhumation: strain distribution over the Tenda massif (Alpine Corsica, France), Tectonophysics, 705, 12-32, 2017.

Bedford, J., Moreno, M., Baez, J. C., Lange, D., Tilmann, F., Rosenau, M., Heibach, O., Oncken, O., Bartsch, M., Rietbrock, A., Tassara, A., Bevis, M., and Vigny, C.: A high-resolution, time-variable afterslip model for the 2010 Maule Mw 8.8, Chile megathrust earthquake, Earth Planet. Sc. Lett., 383, 26-36, 2013.

Berger, A. and Bousquet, R.: Subduction-related metamorphism in the Alps: review of isotopic ages based on petrology and their geodynamic consequences, Geological Society London Special Publications, 298, 117-144, 2008.

Beroza, G. C. and Ide, S.: Slow Earthquakes and Non-volcanic Tremor, Annu. Rev. Earth Pl. Sc., 39, 271-296, 2011.

Bestmann, M. and Prior, D. J.: Intragranular dynamic recrystallization in naturally deformed calcite marble: diffusion accommodated grain boundary sliding as a result of subgrain rotation recrystallization, J. Struct. Geol., 25, 1597-1613, 2003.

Bezert, P. and Caby, R.: Sur l'age post-bartonien des événements tectono-métamorphiques alpines en bourdure orientale de la Corse cristalline, B. Soc. Geol. Fr., 8, 965-971, 1988.

Bos, B. and Spiers, C. J.: Frictional-viscous flow of phyllosilicatebearung rocks: Microphysical model and implications for crustal strength profiles, J. Geophys. Res., 107, 1-13, https://doi.org/10.1029/2001JB000301, 2002.

Burg, J. P. and Laurent, P.: Strain analysis of a shear zone in a granodiorite, Tectonophysics, 47, 15-42, https://doi.org/10.1016/0040-1951(78)90149-X, 1978.

Butler, R. H. W.: Area balancing as a test of models for the deep structure of mountain belts, with specific reference to the Alps, J. Struct. Geol., 52, 2-16, 2013.

Carminati, E. and Doglioni, C.: Alps vs. Apennines: The paradigm of a tectonically asymmetric Earth, Earth-Sci. Rev., 112, 67-96, 2012.

Chester, F. M.: Dynamic recrystallization in semi-brittle faults, J. Struct. Geol., 11, 847-858, 1989.

Cooper, F. J., Platt, J. P., Platzman, E. S., Grove, M. J., and Seward, G.: Opposing shear senses in a subdetachment mylonite zone: Implications for core complex mechanics, Tectonics, 29, TC4019, https://doi.org/10.1029/2009TC002632, 2010.

Derez, T., Pennock, G., Drury, M., and Sintubin, M.: Lowtemperature intracrystalline deformation microstructures in quartz, J. Struct. Geol., 71, 3-23, 2015.

Deseta, N., Andersen, T. B., and Ashwal, L. D.: A weakening mechanism for intermediate depth seismicity? Detailed petrographic and microstructural observation from blueschist facies pseudotachylytes, Cape Corse, Corsica, Tectonophysics 610, 138-149, 2014a.

Deseta, N., Ashwal, L. D., and Andersen, T. B.: Initiating intermediate-depth earthquakes: Insights from a HP-LT ophiolite from Corsica, Lithos, 206, 127-146, 2014b.

Di Rosa, M., De Giorgi, A., Marroni, M., and Vidal., O. Synconvergent exhumation of continental crust: evidence from structural and metamorphic analysis of the Monte $\mathrm{Cecu}$ area, Alpine Corsica (Northern Corsica, France), Geol. J., https://doi.org/10.1002/gj.2857, 2016.
Di Vincenzo, G., Grande, A., Prosser, G., Cavazza, W., and De Celles, P. G.: ${ }^{40} \mathrm{Ar}-{ }^{39} \mathrm{Ar}$ laser dating of ductile shear zones from central Corsica (France): evidence of Alpine (middle to late Eocene) syn-burial shearing in Variscan granitoids, Lithos, 262, 369-383, https://doi.org/10.1016/j.lithos.2016.07.022, 2016.

Evans, B. W.: Phase relations of epidote-blueschists, Lithos, 25, 3 23, 1990.

Faccenna, C., Piromallo, C., Crespo-Blanc, A., Jolivet, L., and Rossetti, F.: Lateral slab deformation and the origin of the western Mediterranean arcs, Tectonics, 23, TC1012, https://doi.org/10.1029/2002, 2004.

Fagereng, A, Hillary, G. W. B., and Diener, J. F. A.: Brittle-viscous deformation, slow slip, and tremor, Geophys. Res. Lett., 41, 4159-4167, https://doi.org/10.1002/2014GL060433, 2014.

Fitzgerald, J. D. and Stünitz, H.: Deformation of granitoids at low metamorphic grades, I. Reactions and grain size reduction, Tectonophysics, 221, 269-297, 1993.

Fournier, M., Jolivet, L., Goffé, B., and Dubois, R.: The Alpine Corsica metamorphic core complex, Tectonics, 10, 1173-1186, 1991.

Fu, Y. and Freymueller, J. T.: Repeated large slow slip events at the south central Alaska subduction zone, Earth Planet. Sci. Lett., 375, 303-311, 2013.

Fusseis, F. and Handy, M. R.: Micromechanisms of shear zone propagation at the brittle-viscous transition, J. Struct. Geol., 30, 1242-1253, 2008.

Gapais, D., Bale, P., Choukroune, P., Cobbold, P. R., Mahjoub, Y., and Marquer, D.: Bulk kinematics from shear zone patterns: some field examples, J. Struct. Geol., 9, 635-646, https://doi.org/10.1016/0191-8141(87)90148-9, 1987.

Garfagnoli, F., Menna, F., Pandeli, E., and Principi, G.: Alpine metamorphic and tectonic evolution of the Inzecca-Ghisoni area (southern Alpine Corsica, France), Geol. J., 44, 191-210, 2009.

Gibbons, W. and Horak, J.: Alpine metamorphism of Hercynian hornblende granodiorite beneath the blueschist facies schistes lustre's nappe of NE Corsica, J. Metamor. Geol., 2, 95-113, 1984.

Goncalves, P. Poilvet, J.-C., Oliot, E., Trap, P., and Marquer, D.: How does shear zone nucleate? An example from the Suretta nappe (Swiss Eastern Alps), J. Struct. Geol., 86, 166-180, 2016.

Guermani, A. and Pennacchioni, G: Brittle precursors of plastic deformation in a granite: An example from the Mont Blanc Massif (Helvetic, western Alps), J. Struct. Geol., 20, 135-148, 1998.

Gueydan, F., Brun, J. P., Philippon, M., and Noury, M.: Sequential extension as record of Corsica rotation during Apennines slab roll-back, Tectonophysics, 710/711, 149-161, https://doi.org/10.1016/j.tecto.2016.12.028, 2016.

Hacker, B. R., Peacock, S. M., Abers, G. A., and Holloway S. D.: Subduction factory, 2. Are intermediatedepth earthquakes in subducting slabs linked to metamorphic dehydration reactions?, J. Geophys. Res., 108, 2030, https://doi.org/10.1029/2001JB001129, 2003.

Handy M. R. and Brun, J. P.: Seismicity, structure and strength of the continental lithosphere, Earth Planet. Sc. Lett., 223, 427-441, 2004.

Handy, M. R. and Stünitz, H.: Strain localization by fracturing and reaction-weakening - a mechanism for initiating exhumation of subcontinental mantle beneath rifted margins, in: Deformation mechanisms, rheology and tectonics: current status and future 
perspectives, edited by: De Meer, S., Drury, M. R., De Bresser, J. H. P., and Pennock, G. M., Geological Society of London Special Publication, 200, 387-407, 2002.

Handy, M. R., Hirth, G., and Burgmann, R.: Continental fault structure and rheology from frictional-to-viscous transition downward, in: Tectonic Faults: Agents of Change on a Dynamic Earth, edited by: Handy, M. R., Hirth, G., and Hovious, N., Dahlem Workshop Reports, MIT Press, 139-181, 2007.

Hayman, N. W. and Lavier, L. L.: The geologic record of deep episodic tremor and slip, Geology, 42, 195-198, https://doi.org/10.1130/G34990.1, 2014.

Healy, D., Reddy, S. M., Timms, N. E., Gray, E. M., and Vitale Brovarone, A.: Trench parallel fast axes of seismic anisotropy due to fluid-filled cracks in subducting slabs, Earth Planet. Sc. Lett., 283, 75-86, 2009.

Hirth, G. and Tullis, J.: Dislocation creep regimes in quartz aggregates, J. Struct. Geol., 14, 145-159, 1992.

Hirth, G., Teyssier, C., and Dunlop, W. J.: An evaluation of quartzite flow laws based on comparisons between experimentally and naturally deformed rocks, Int. J. Earth Sci., 90, 77-87, 2001.

John, T., Medvedev, S., Rüpke, L. H., Andersen, T. B., Podladchikov, Y. Y., and Austrheim, Å.: Generation of intermediatedepth earthquakes by self-localizing thermal runaway, Nat. Geosci., 2, 137-140, https://doi.org/10.1038/NGEO419, 2009.

Jolivet, L., Dubois, R., Fournier, M., Goffé, B., Michard, A., and Jourdan, C.: Ductile extension in Alpine Corsica, Geology, 18, 1007-1010, 1990.

Kjøll, H. J., Viola, G., Menegon, L., and Sørensen, B. E.: Brittle-viscous deformation of vein quartz under fluid-rich lower greenschist facies conditions, Solid Earth, 6, 681-699, https://doi.org/10.5194/se-6-681-2015, 2015.

Kohlstedt, D. L., Evans, B., and Mackwell, S. J.: Strength of the lithosphere: Constraints imposed by laboratory experiments, J. Geophys. Res., 100, 17857-17602, 1995.

Kruhl, J. H.: Prism- and basal-plane parallel subgrain boundaries in quartz: a microstructural geothermobarometer, J. Metamorph. Geol., 14, 581-589, 1996.

Küster, M. and Stöckhert, B.: High differential stress and sublithostatic pore fluid pressure in the ductile regime - microstructural evidence for short-term post-seismic creep in the Sesia Zone, Western Alps, Tectonophysics, 303, 263-277, 1999.

Lahondére, D.: Les schistes blues et les eclogites a lawsonite des unités continentals et océanique de la Corse alpine: Nouvelles donnée e pétrologique et structurales (Corse), Documents du BRGM, 240 pp., 1996.

Lamb, S.: Shear stresses on megathrusts: Implications for mountain building behind subduction zones, J. Geophys. Res., 111, B07401, https://doi.org/10.1029/2005JB003916, 2006.

Liu, Y. and Rice, J. R.: Spontaneous and triggered aseismic deformation transients in a subduction fault model, J. Geophys. Res., 112, B09404, https://doi.org/10.1029/2007JB004930, 2007.

Maggi, M., Rossetti, F., Corfu, F., Theye, T., Andersen, T. B., and Faccenna, C.: Clinopyroxene-rutile phyllonites from the East Tenda Shear Zone (Alpine Corsica, France): pressuretemperature-time constraints to the Alpine reworking of Variscan Corsica, J. Geol. Soc., 169, 723-732, 2012.

Magott, R., Fabbri, O., and Fournier, M.: Polyphase ductile/brittle deformation along a major tectonic boundary in an ophi- olitic nappe, Alpine Corsica: Insights on subduction zone intermediate-depth asperities, J. Struct. Geol., 87, 95-114, 2016.

Malatesta, C., Federico, L., Crispini, L., and Capponi, G.: Fluid-controlled deformation in blueschist-facies conditions: plastic vs brittle behaviour in a brecciated mylonite (Voltri Massif, Western Alps, Italy), Geol. Mag., https://doi.org/10.1017/S0016756816001163, 2017.

Malasoma, A., Marroni, M., Musumeci, G., and Pandolfi, L.: High pressure mineral assemblage in granitic rocks from continental units in Alpine Corsica, France, Geol. J., 41, 49-59, 2006

Mancktelow, N. S.: How ductile are ductile shear zones?, Geology, 34, 345-348, 2006

Mancktelow, N. S. and Pennacchioni, G.: The control of precursor brittle fracture and fluidrock interaction on the development of single and paired ductile shear zones, J. Struct. Geol., 4, 645661, 2005.

Massonne, H. J. and Szpurka, Z.: Thermodynamic properties of white micas on the basis of high-pressure experiments in the systems $\mathrm{K}_{2} \mathrm{OMgO}-\mathrm{Al}_{2} \mathrm{O}_{3}-\mathrm{SiO}_{2}-\mathrm{H}_{2} \mathrm{O}$ and $\mathrm{K}_{2} \mathrm{O}-\mathrm{FeO}-\mathrm{Al}_{2} \mathrm{O}_{3}-\mathrm{SiO}_{2}-$ $\mathrm{H}_{2} \mathrm{O}$, Lithos, 41, 229-250, 1997.

Mattauer, M., Faure, M., and Malavieille, J.: Transverse lineation and large scale structures related to Alpine obduction in Corsica, J. Struct. Geol., 3, 401-409, 1981.

Mazzoli, S., Vitale, S., Del Monaco, G., Guerriero, G., Margottini, C., and Spizzichino, D.: "Diffuse faulting" in the Machu Pichu granitoid pluton, Eastern Cordillera, Perù, J. Struct. Geol., 31, 1395-1408, 2009.

Meneghini, F., Di Toro, G., Rowe, C. D., Moore, J. C., Tsutsumi, A., and Yamaguchi, A.: Record of mega-earthquakes in subduction thrusts: The black fault rocks of Pasagshak Point (Kodiak Island, Alaska), Geol. Soc. Am. Bull., 122, 1280-1297, 2010.

Menegon, L. and Pennacchioni, G.: Local shear zone pattern and bulk deformation in the Gran Paradiso metagranite (NW Italian Alps), Int. J. Earth Sci., 99, 1805-1825, 2010.

Menegon, L., Piazolo, S., and Pennacchioni, G.: The effect of Dauphiné twinning on plastic strain in quartz, Contrib. Mineral. Petr., 161, 635-652, 2011.

Menegon, L., Stünitz, H., Nasipuri, P., Heilbronner, R., and Svahnberg, H.: Transition from fracturing to viscous ow in granulite facies perthitic feldspar (Lofoten, Norway), J. Struct. Geol., 48, 95-112, 2013.

Molli, G.: Localizzazione di zone di taglio HP/LT su precursori fragili: Un esempio dalla Corsica Alpina, Rend. Soc. Geol. It., 4, 270-271, 2007.

Molli, G.: Northern Apennine-Corsica orogenic system: an updated review, in: Tectonic Aspects of the Alpine-DinarideCarpathian System, edited by: Siegesmund, S., Fugenschuh, B., and Froitzheim, N., Geol. Soc., 298, 413-442, 2008.

Molli, G. and Malavieille, J.: Orogenic processes and the Alps/Apennines geodynamic evolution: insights from Taiwan, Int. J. Earth Sci., 100, 1207-1224, https://doi.org/10.1007/s00531-010-0598-y, 2011.

Molli, G., Malasoma, A., and Meneghini, F.: Brittle precursors of HP/LT microscale shear zone: a case study from Alpine Corsica, 15th Conference of Deformation, Rheology and Tectonics, Zurich, Abstract Volume, 153 pp., 2005.

Molli, G., White, J. C., Kennedy, L., and Taini, V.: Low-temperature deformation of limestone, Isola Palmaria, Northern Apennine, Italy - The role of primary textures, precursory veins and in- 
tracrystalline deformation in localization, J. Struct. Geol., 33, 255-270, https://doi.org/10.1016/j.jsg.2010.11.015, 2011.

Montési, L. G. J. and Hirth, G.: Grain size evolution and the rheology of ductile shear zones: From laboratory experiments to postseismic creep, Earth Planet. Sc. Lett., 211, 97-110, https://doi.org/10.1016/S0012-821X(03)00196-1, 2003.

Neumann, B.: Texture development of recrystallised quartz polycrystals unravelled by orientation and misorientation characteristics, J. Struct. Geol., 22, 1695-1711, 2000.

Ozawa, S., Murakami, M., Kaidzu, M., Tada, T., Sagiya, T., Hatanaka, Y., Yarai, H., and Nishimura, T.: Detection and monitoring of ongoing aseismic slip in the Tokai region, central Japan, Science, 298, 1009-1012, 2002.

Passchier, C. W. and Trouw, R. A. J.: Microtectonics, Springer, 366 pp., 2011.

Pec, M., Stünitz, H., and Heilbronner, R.: Semi-brittle deformation of granitoid gouges in shear experiments at elevated pressures and temperatures, J. Struct. Geol., 38, 200-221, 2012.

Peng, Z. and Gomberg, J.: An integrated perspective of the continuum between earthquakes and slow slip phenomena, Nat. Geosci., 3, 599-607, 2010.

Pennacchioni, G. and Cesare, B. Ductile-brittle transition in preAlpine amphibolite facies mylonites during evolution from water-present to water-deficient conditions (Mont Mary, Italian Western Alps), J. Metamor. Geol., 15, 777-791, 1997.

Pennacchioni, G.: Control of the geometry of precursor brittle structures on the type of ductile shear zone in the Adamello tonalites, Southern Alps (Italy), J. Struct. Geol., 27, 627-644, 2005.

Pennacchioni, G. and Mancktelow, N. S.: Nucleation and initial growth of a shear zone network within compositionally and structurally heterogeneous granitoids under amphibolite facies conditions, J. Struct. Geol., 29, 1757-1780, 2007.

Pennacchioni, G. and Zucchi, E.: High temperature fracturing and ductile deformation during cooling of a pluton: The Lake Edison granodiorite (Sierra Nevada batholith, California), J. Struct. Geol., 50, 54-81, 2013.

Pennacchioni, G., Di Toro, G., Brack, P., Menegon, L., and Villa, I. M.: Brittle-ductile-brittle deformation during cooling of tonalite (Adamello, Southern Italian Alps), Tectonophysics, 427, 171197, 2006.

Pittarello, L., Pennacchioni, G., and Di Toro, G.: Amphibolitefacies pseudotachylytes in Premosello metagabbro and felsic mylonites (Ivrea Zone, Italy), Tectonophysics, 580, 43-57, 2012.

Platt, J. P. and Behr, W. M.: Lithospheric shear zones as constant stress experiments, Geology, 39, 127-130, https://doi.org/10.1130/G31561.1, 2011.

Polino, R., Dal Piaz, G. V., and Gosso, G.: Tectonic erosion at the Adria margin and accretionary process for the Cretaceous orogeny of the Alps, in: Deep Structure of the Alps, edited by: Roure, F., Heitzman, P., and Polino, R., Volume Speciale Società Geologica Italiana, Roma, 1, 345-367, 1990.

Prior, D. J., Wheeler, J., Peruzzo, L., Spiess, R., and Storey, G.: Some garnet microstructures: an illustration of the potential of orientation maps and misorientation analysis in microstructural studies, J. Struct. Geol., 24, 999-1011, 2002.

Rogers, G. and Dragert, H.: Episodic tremor and slip on the Cascadia subduction zone: The chatter of silent slip, Science, 300, 1942-1943, 2003.
Ramsay, J. G. and Graham, R. H.: Strain variation in shear belts, Can. J. Earth Sci., 7, 786-813, 1970.

Rosenberg, C. and Kissling, E.: Three-dimensional insight into Central-Alpine collision: Lower-plate or upper-plate indentation?, Geology, 41, 1219-1222, https://doi.org/10.1130/G34584.1, 2013.

Rossi, P., Durand-Delga, M., Lahondére, J. C., and Lahondére, D.: Carte géologique de la France à $1 / 50000$, feuille Santo Pietro di Tenda, BRGM, 2003.

Rutter, E. H: On the nomenclature of mode of failure transitions in rocks, Tectonophysics, 122, 381-387, 1986.

Schiffman, P. and Day, H. W.: Petrologic methods for the study of Very Low-grade metabasites in Low-Grade metamorphism, edited by: Frey, M. and Robinson, D., Blackwell Publishing Ltd., Oxford, UK, Chap. 4, 108-144, https://doi.org/10.1002/9781444313345.ch4, 2009.

Schmid, S. M. and Handy, M. R.: Towards a genetic classification of fault rocks: Geological usage and tectonophysical implications, in: Controversies in modern geology, edited by: Muller, D. W., Mc Kenzie, J. A., and Weissert, H., London, Academic Press, 339-361, 1991.

Schmid, S. M., Pfiffer, O. A., Froitzheim, N., Schonborn, G., and Kissling, E.: Geophysical-geological transect and tectonic evolution of the Swiss-Italian Alps, Tectonics, 12, 1036-1064, 1996.

Scholz, C. H.: The brittle-plastic transition and the depth of seismic faulting, Geol. Rundsch., 77, 319-328, 1988.

Scholz, C. H.: The Mechanics of Earthquakes and Faulting, 2nd Edn., Cambridge University Press, 2002.

Segall, P. and Simpson, C.: Nucleation of ductile shear zones on dilatant fractures, Geology, 14, 56-59, 1986.

Shelly, D. R. G., Beroza, G. C., Ide, S., and Nakamura, S.: Lowfrequency earthquakes in Shikouku, Japan, and their relationship to episodic tremor and slip. Nature, 442, 188-191, 2006.

Shimamoto, T.: The origin of S-C mylonites and a new fault-zone model, J. Struct. Geol., 11, 51-64, 1989.

Shimamoto, T. and Logan, J. M.: Velocity-dependent behaviours of simulated halite shear zones: an analog for silicates, Am. Geophys. Mongr., 37, 49-63, 1986.

Sibson, R. H.: Fault rocks and fault mechanisms, J. Geol. Soc. Lond., 133, 191-213, 1977.

Sibson, R. H.: Transient discontinuities in ductile shear zones, J. Struct. Geol., 2, 165-171, 1980.

Sibson, R. H.: Continental fault structure and the shallow earthquake source, J. Geol. Soc. Lond., 140, 741-767, 1983.

Sibson, R. H.: A note on fault reactivation, J. Struct. Geol., 7, 751754, 1985.

Simpson, C.: Deformation of granitic rocks across the brittle-ductile transition, J. Struct. Geol., 7, 503-511, 1985.

Simpson, C.: Fabric development in brittle-to-ductile shear zones, Pure Appl. Geophys., 124, 269-288, 1986.

Stipp, M. and Tullis, J.: The recrystallized grain size piezometer for quartz, Geophys. Res. Lett., 30, 2088, https://doi.org/10.1029/2003GL018444, 2003.

Stipp, M., Stünitz, H., Heilbronner, R., and Schmid, S. M.: The eastern Tonale fault zone: a "natural laboratory" for crystal plastic deformation of quartz over a temperature range from 250 to $700^{\circ}$ C, J. Struct. Geol., 24, 1861-1884, 2002.

Stöckhert, B.: Stress and deformation in subduction zones - insight from the record of exhumed metamorphic rocks, in: Geological 
Society of London Special Publication, edited by: De Meer, S., Drury, M. R., De Bresser, J. H. P., and Pennock, G. M., Geological Society of London Special Publication, London, 200, 255274, 2002.

Takagi, H., Goto, K., and Shigematsu, N.: Ultramylonite bands derived from cataclasite and pseudotachylyte in granites, northeast Japan, J. Struct. Geol., 22, 1325-1339, 2000.

Tödheide, K.: Water at high temperatures and pressures, in: Water: A Comprehensive Treatise, edited by: Franks, F., Springer, New York, vol. 1, chap. 13, 463-514, 1972.

Trepmann, C. A., Stockhert, B., Dorner, D., Moghadam, E. H., Kuster, M., and Roller, K.: Simulating coseismic deformation of quartz in the middle crust and fabric evolution during postseismic stress relaxation - an experimental study, Tectonophysics, 442, 83-104, 2007.

Trepmann, C. A., Hsu, C., Hentschel, F., Döhler, K., Schneider, C., and Wichmann, V.: Recrystallization of quartz after lowtemperature plasticity - The record of stress relaxation below the seismogenic zone, J. Struct. Geol., 95, 77-92, 2017.

Tribuzio, R. and Giacomini, F., Blueschist facies metamorphism of peralkaline rhyolites from the Tenda crystalline massif (northern Corsica): evidence for involvement in the Alpine subduction event?, J. Metamorph. Geol., 20, 513-526, 2002.

Van Daalen, M., Heilbronner, R., and Kunze, K.: Orientation analysis of localized shear deformation in quartz fibres at the brittleductile transition, Tectonophysics, 303, 83-107, 1999.

Vannucchi, P., Remitti, F., and Bettelli, G.: Geological record of fluid flow and seismogenesis along an erosive subducting plate boundary, Nature, 451, 7179, 699-703, 2008.

Vernooij, M. G., den Brok, B., and Kunze, K.: Development of crystallographic preferred orientations by nucleation and growth of new grains in experimentally deformed quartz single crystals, Tectonophysics, 427, 35-53, 2006.
Viola, G., Mancktelow, N. S., and Miller, J. A.: Cyclic frictionalviscous slip oscillations along the base of an advancing nappe complex: insights into brittle-ductile nappe emplacement mechanisms from the Naukluft Nappe Complex, central Namibia, Tectonics, 25, TC3016, https://doi.org/10.1029/2005tc001939, 2006.

Vitale Brovarone, A., Beyssac, O1., Malavieille, J., Molli, G., Beltrando, M., and Compagnoni, R.: Stacking and metamorphism of continuous segments of subducted lithosphere in a high-pressure wedge: The example of Alpine Corsica (France), Earth-Sci. Rev., 116, 35-56, 2013.

Wallace, L. M. and Beavan, J.: Diverse slow slip behavior at the Hikurangi subduction margin, New Zealand, J. Geophys. Res., 115, B12402, https://doi.org/10.1029/2010JB007717, 2010.

White, S. H.: Natural creep of quartzites, Nat. Phys. Sci., 234, 175177, 1971.

White, S. H.: Syntectonic recrystallisation and texture development in quartz, Nature, 244, 276-278, 1973.

White, J. C.: Transient discontinuities revisited: Pseudotachylyte, plastic instability and the influence of low pore fluid pressure on deformation processes in the mid-crust, J. Struct. Geol., 18, 1471-1477, 1996.

White, J. C.: Paradoxical pseudotachylyte - Fault melt outside the seismogenic zone, J. Struct. Geol., 38, 11-20, 2012.

White, J. C. and White, S. H.: Semi-brittle deformation within the Alpine fault zone, New Zealand, J. Struct. Geol., 5, 579-589, 1982

Zibra, I., Kruhl, J. H., and Braga, R.: Late Palaeozoic deformation of post-Variscan lower crust: shear zone widening due to strain localization during retrograde shearing, Int. J. Earth Sci., 99, 973991, 2010. 